Biogeosciences Discuss., 6, 2863-2912, 2009

www.biogeosciences-discuss.net/6/2863/2009/

(C) Author(s) 2009. This work is distributed under

Seasonal variation in ecosystem parameters derived from FLUXNET data

M. Groenendijk et al.

\title{
Seasonal variation in ecosystem parameters derived from FLUXNET data
}

\section{Groenendijk, M. K. van der Molen, and A. J. Dolman}

VU University Amsterdam, Faculty of Earth and Life Sciences, Department of Hydrology and Geo-environmental Sciences, De Boelelaan 1085, 1081 HV Amsterdam, The Netherlands

Received: 28 January 2009 - Accepted: 1 March 2009 - Published: 11 March 2009

Correspondence to: M. Groenendijk (margriet.groenendijk@ falw.vu.nl)

Published by Copernicus Publications on behalf of the European Geosciences Union.

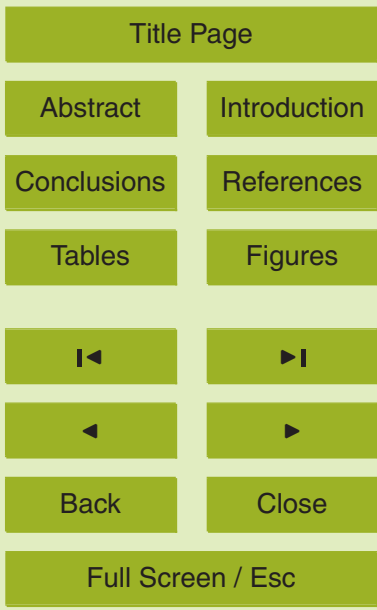

Printer-friendly Version 


\section{Abstract}

The carbon dioxide sink is in a complex way related to weather and climate. In order to better understand the relationship and feedbacks, we present a methodology to simulate observed carbon dioxide flux data with a simple vegetation model (5PM)

5 with weekly varying model parameters. The model parameters explain the interaction between vegetation and seasonal climate more general than the flux data. Two parameters $\left(R_{\text {ref }}\right.$ and $\left.E_{0}\right)$ are related to ecosystem respiration and three parameters $\left(J_{m}\right.$, $\alpha$ and $\lambda$ ) to photosynthesis and transpiration. We quantified the weekly variability of ecosystem parameters as a function of vegetation type and climate region.

After statistical quality checks 121 FLUXNET sites were available for analysis of the weekly varying model parameters. The simulations of these sites have high correlation coefficients $\left(r^{2}=0.6\right.$ to 0.8$)$ between the observed and simulated carbon and water fluxes. With weekly parameters we determined average seasonal cycles for the different combinations of vegetation type and climate regions (PFTs). The variation between

15 PFTs is large, which provides an excellent dataset to study the differences in ecosystem characteristics. In general we observed that needleleaf forests and grasslands in warmer climates have relatively constant parameter values during the year. Broadleaf forests in all climate regions have large seasonal variation for each of the five parameters. In boreal regions parameter values are always lower than in temperate regions.

20 A large seasonality of the model parameters indicates a strong relation between vegetation and climate. This suggests that climate change will have the largest impact on the terrestrial carbon fluxes in boreal regions and for deciduous forests, and less for grasslands and evergreen forests.

\section{Introduction}

25 The relationship between vegetation and climate is of fundamental importance in understanding and assessing potential feedbacks of vegetation on climate. The steady
BGD

6, 2863-2912, 2009

Seasonal variation in ecosystem

parameters derived from FLUXNET data

M. Groenendijk et al.

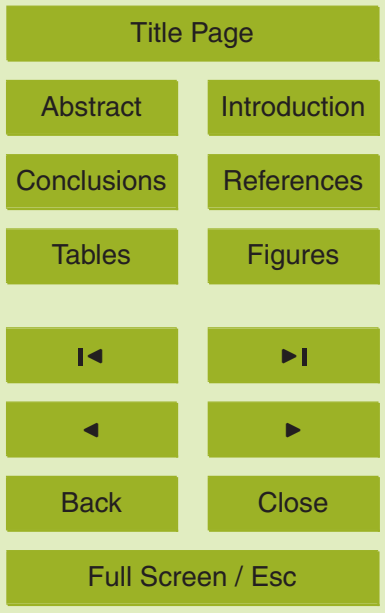

Printer-friendly Version

Interactive Discussion 
state relationship between vegetation and climate was expressed by Köppen (1918, 1936), who developed a classification of climatic regions based on patterns in native vegetation. Holdridge (1947) classified life zones as a function of temperature and precipitation. These classifications represent biomes, in which a number of different 5 vegetation types may co-exist (e.g., savanna). When vegetation models were coupled to climate models, plant functional types (PFTs) were introduced to describe the specific properties of particular vegetation types with regard to the exchange of radiation, water and energy between the vegetation and the atmosphere (e.g., Dickinson et al., 1986; Sellers et al., 1986). Virtually all climate models use PFTs as the basis for their 10 vegetation description.

PFTs were initially applied as a steady state in the climate models, studying the effects of deforestation (Eltahir and Bras, 1996; Hahmann and Dickinson, 1997; Costa and Foley, 1999). With the increasing interest in climate change research, vegetation models were coupled to carbon cycle models (e.g., Foley et al., 1998; Woodward 15 et al., 1998; Friend and Cox, 1995), in which vegetation characteristics were allowed to change during simulations, in some models even across PFT boundaries. These latest developments put high requirements on the PFT formulations. This is illustrated by Kleidon et al. (2007), who found that strict separation of vegetation in PFTs may artificially cause multiple steady-states of the Earth's climate-vegetation system. The 20 assumption that parameters in carbon exchange models are conveniently grouped into PFTs, just as parameters for energy exchange are, apparently violates smooth transitions between different ecosystem types.

A number of efforts have been made to relate terrestrial carbon fluxes, observed at flux stations as the net ecosystem exchange (NEE), to climate (e.g., Falge et al., 2002; Law et al., 2002; Reichstein et al., 2007). From these efforts it appears that NEE cannot be explained well by climate on the annual time scale (Baldocchi, 2008). After partitioning into respiration and photosynthesis temperature appears as the main driver of annual respiration, but in arid and tropical regions soil moisture also is an important variable (Irvine and Law, 2002). For photosynthesis the main drivers are the

BGD

6, 2863-2912, 2009

Seasonal variation in ecosystem

parameters derived from FLUXNET data

M. Groenendijk et al.

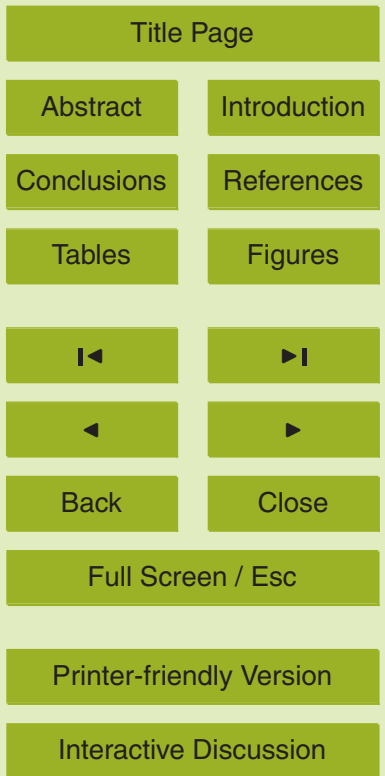


water vapour deficit, temperature and leaf area index (van Dijk et al., 2005; Reichstein et al., 2007; Lindroth et al., 2008). An important factor controlling the annual NEE is the growing season length, with an almost linear increase of carbon uptake with an increasing growing season (Leuning et al., 2005). Looking more into the seasonal 5 variation helps to improve the understanding of the relations between carbon fluxes and climate.

An alternative, slightly more complex way to search for relationships between carbon fluxes and climate, is to use a simple vegetation model, optimize the model parameters to best describe the observed fluxes, and then study patterns in the parameter 10 values. Such a model should be simple, while at the same time contain parameters that describe fundamental properties of the ecosystem. We have developed such a simple vegetation model with only five parameters (5PM), two to describe ecosystem respiration and three to describe photosynthesis and transpiration and an associated optimization method described in this paper.

15 On the very short term, minutes to hours, vegetation responds to weather variation by controlling the opening of stomata in the leaves, in order to prevent excessive water loss while optimizing $\mathrm{CO}_{2}$ uptake for photosynthesis. This represents regulation on the shortest time scale, which for practical reasons we call stomatal control. The model is capable of describing the diurnal cycles of carbon and water exchange between the ecosystem and the atmosphere and the response to diurnal changes in temperature and vapor pressure deficit (van der Tol et al., 2007). As such, there is no need to optimize the parameters on time scales shorter than daily and by using the 5PM model we effectively remove the diurnal time scale from the data set. Any variation in the optimized parameters thus represents changes in ecosystem characteristics on time scales longer than one day, for which we will investigate the variability as potentially related to environmental conditions.

On the short term of days to weeks, ecosystems may respond to variations in weather by semi-permanent physical adaptation, such as growing new leaves after a period of drought, or growing extra roots. This type of regulation changes the vegeta-

Seasonal variation in ecosystem

parameters derived from FLUXNET data

M. Groenendijk et al.

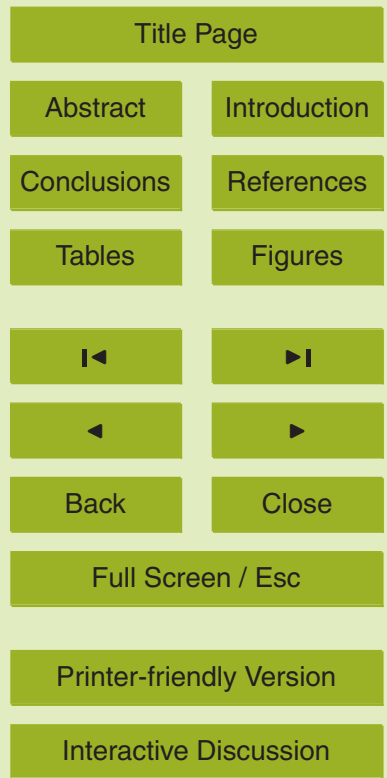


tion characteristics and should be reflected in changes in parameter values at ecosystem level. We hypothesize that the parameter values, optimized on weekly time scales show seasonal cycles and respond to extreme conditions, thus quantifying the regulation capacity of the ecosystem. In the medium term, seasons to years, the effects 5 of regulation are integrated to variations in allocation of assimilated carbon to roots, stems and branches, and leaves, while still inter-annual weather variations may cause regulation. On this time scale, the effects of regulation may lag behind the timing of the cause: a wet winter may recharge soil moisture storage, cause abundant leaf growth and enhanced photosynthesis in the following summer. On the long term of decades, ecosystems adapt to repeated occurrences of climate extremes and competition with other ecosystem types. Parameter values optimized on this time scale are expected to converge into groups (plant functional types) or onto a sliding scale of vegetation characteristics.

The objective of this paper is to quantify the short term variability of ecosystem pa15 rameters of different vegetation types and climate regions. Specific questions we want to address: (1) are the model parameters clearly different between PFTs and (2) do the model parameters vary in an understandable way and (3) does the variation in model parameters have implications for our understanding of the feedback between vegetation and climate? In Sect. 2.1 we describe the 5PM model, which simulates the project are described in Sect. 2.2. The model is optimized with these observed fluxes and climate variables to derive the model parameters. Model quality, seasonal variation of model parameters and relations with climate variables are presented in Sect. 3 and discussed in Sect. 4.

BGD

6, 2863-2912, 2009

Seasonal variation in ecosystem

parameters derived from FLUXNET data

M. Groenendijk et al.

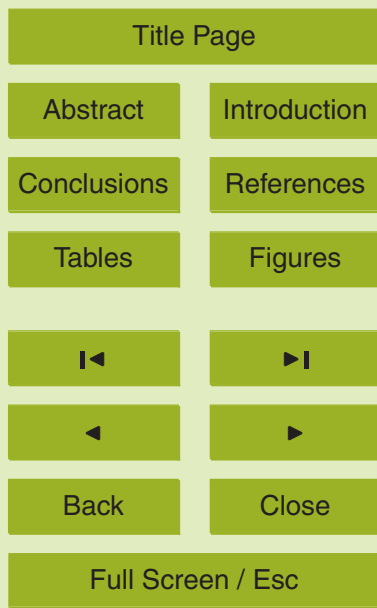

Printer-friendly Version

Interactive Discussion 


\section{Methodology}

\subsection{Simulations}

In this section we describe 5PM (5 Parameter Model), which simulates carbon and water exchange between the vegetation and the atmosphere. The model consists of 5 two modules, one for ecosystem respiration (Sect. 2.1.1) and one for photosynthesis and transpiration (Sect. 2.1.2). The model requires input variables air temperature, vapour pressure deficit and global radiation.

\subsubsection{Ecosystem respiration}

Ecosystem respiration $\left(R_{e}\right)$ consists of two components, soil (heterotrophic) respiration 10 and plant (autotrophic) respiration. Heterotrophic respiration is the carbon release due to decomposition of organic matter in the soil. It is a function of availability of organic matter (amount, composition and aeration) and microbiological activity (microbial pool, temperature, and soil moisture availability). Autotrophic respiration consists of maintenance and growth respiration and it occurs below ground in the roots and above ground in the branches and leaves of the vegetation. It is a function of the amount and composition of below and above ground biomass, and temperature, biological activity and weather (history).

Due to the different sub-processes, ecosystem respiration is complex to model. However, there are a few simplifications that may be made. On short time scales (< years) soil organic matter and biomass can be considered constant and variations in $R_{e}$ are caused by weather. On long time scales ( $>10$ years), $R_{e}$ is controlled by the pools of carbon in organic matter and biomass. The pools represent the balance between production and decomposition.

Since we focus on short term processes, we will consider the pools to be fixed and

Seasonal variation in ecosystem

parameters derived from FLUXNET data

M. Groenendijk et al.

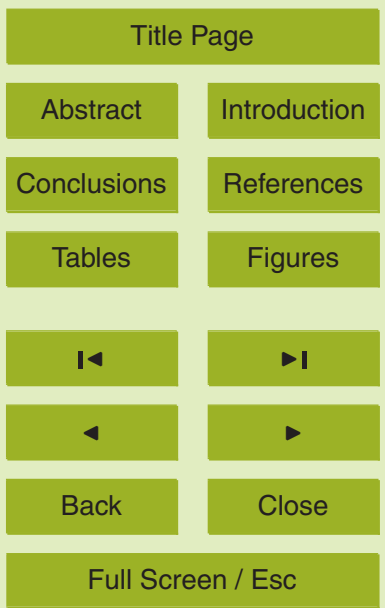

Printer-friendly Version

Interactive Discussion 
function of Lloyd and Taylor (1994).

$R_{e}=R_{\text {ref }} \times \mathrm{e}^{E_{0}\left(1 /\left(T_{\text {ref }}-T_{0}\right)-1 /\left(T_{a}-T_{0}\right)\right)}$

BGD

The ecosystem respiration module uses two parameters, $R_{\text {ref }}$ and $E_{0}$. $R_{\text {ref }}$ $\left(\mu \mathrm{mol} \mathrm{m}{ }^{-2} \mathrm{~s}^{-1}\right)$ is the respiration rate at the reference temperature $\left(T_{\text {ref }}, 283.15 \mathrm{~K}\right), E_{0}$ 5 is the activation energy $(\mathrm{K})$ and $T_{0}$ is a constant of $227.13 \mathrm{~K}$. In this way we lump autotrophic and heterotrophic respiration. We use air temperature and not soil temperature in Eq. (1), because it has been shown by van Dijk and Dolman (2004) and Stoy et al. (2006) that when using air temperature the observed and simulated frequency distributions of $R_{e}$ match better, and parameter values are more consistent.

\subsubsection{Photosynthesis and transpiration}

Photosynthesis and transpiration are closely linked through stomatal conductance of plants. Stomatal conductance regulates both transpiration and photosynthesis. At the diurnal timescale Cowan (1977) assumed that plants optimize their stomatal conductance to maximize photosynthesis for a given amount of transpiration. In this optimality 15 hypothesis the intrinsic water use efficiency $(\lambda)$ defines the ratio between water loss $(E)$ and carbon production $(A)$ as a function of stomatal conductance $\left(g_{s}\right)$.

$\lambda=\frac{\delta E / \delta g_{s}}{\delta A / \delta g_{s}}$

Ecosystem water and carbon fluxes are simulated as a function of $J_{m}, \alpha$ and $\lambda$. The full equations are given in Appendix A. $J_{m}$ is the maximum potential electron transport

rate and $\alpha$ is the quantum yield or light use efficiency. $J_{m}$ and $\alpha$ describe the amount of absorbed photosynthetic active radiation, which with the internal $\mathrm{CO}_{2}$ concentration defines the photosynthesis rate. Because we found that simulated photosynthesis was limited by light for the largest part of time, and not $\mathrm{CO}_{2}$ concentration, we chose to present only $J_{m}$ and not $V_{c m}$ in the results.
6, 2863-2912, 2009

Seasonal variation in ecosystem

parameters derived from FLUXNET data

M. Groenendijk et al.

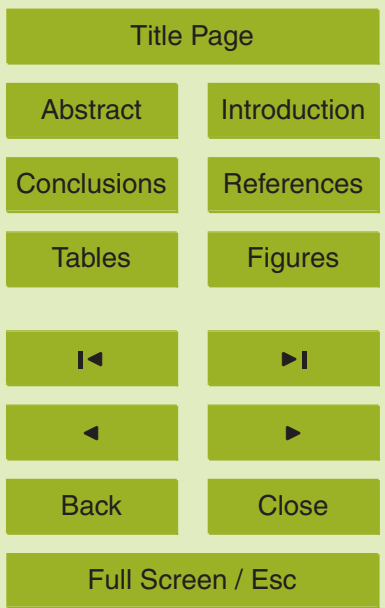

Printer-friendly Version

Interactive Discussion 


\subsection{Observations}

With environmental variables and observations of the carbon and water fluxes, the parameters can be derived by inverting the model. We use a database of carbon and water fluxes measured with the eddy covariance technique. See Table B1 for 5 a complete list and Table 1 for a summary of sites within PFTs used in this study. The data are available in the form of half-hourly averages. All data is processed in a harmonized manner within the FLUXNET project (Baldocchi et al., 2001; Baldocchi, 2008) and retrieved from the database in April $2008^{1}$. Data processing is described in Papale et al. (2006), Reichstein et al. (2005), Moffat et al. (2007) and Papale and 10 Valentini (2003).

The observed latent heat flux ( $L E)$ consists of transpiration from vegetation and evaporation from the soil. We use only dry periods with no precipitation, or no precipitation during the previous three hours. For these periods it is assumed that $L E$ is equal to the transpiration of vegetation.

15 The observed carbon flux represents the net exchange of carbon between the ecosystem and the atmosphere and consists of different fluxes. The observed flux $\left(F_{c}\right)$ plus a storage term within the vegetation is assumed to be equal to NEE. Nighttime NEE is assumed to be equal to ecosystem respiration $\left(R_{e}\right)$, because during the night there is no photosynthetic activity. Selection criteria for turbulent nighttime data are thresholds of global radiation $\left(R_{g}\right)$ and friction velocity $\left(u_{*}\right)$. The $R_{g}$ threshold is set to $0 \mathrm{~W} \mathrm{~m}^{-2}$. The $u_{*}$ threshold determination is based on the procedure as described in Gu et al. (2005). The data is divided into subsets of three month periods. For each of the subsets (reference sample) the threshold is estimated by a Moving Point Test (MPT). First, outliers are removed when nighttime NEE is larger than three standard deviations of the reference sample. Secondly, the fluxes are ordered from low to high $u_{*}$. Thirdly, a moving sample ( $n=30$, starting with lowest $u_{*}$ values) of the data is compared with the reference sample with a statistical t-test, to determine if the sample has

\footnotetext{
${ }^{1}$ www.fluxdata.org, dataset DS2
}

BGD

6, 2863-2912, 2009

Seasonal variation in ecosystem

parameters derived from FLUXNET data

M. Groenendijk et al.

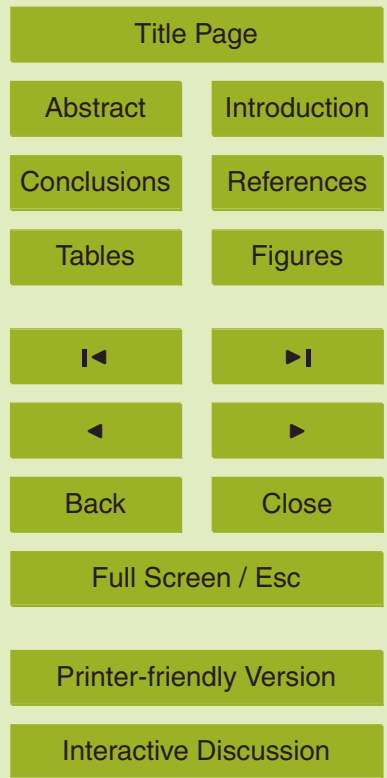


a different mean NEE. This step is repeated by moving the subset with one step to a higher value of $u_{*}$ until the sample has an equal distribution as the subset. This point is the threshold $u_{*}$, below which the turbulence is too low to observe reliable nighttime fluxes. Instead of using the thresholds of the three month periods, we decided to use 5 the highest threshold for each site, which is comparable to the conservative approach by Reichstein et al. (2005). In Table B1 $u_{*}$ thresholds of individual sites can be found.

\subsection{Model parameter estimation}

\subsubsection{Model optimization}

The respiration module is optimized first using the simplex search method (Lagarias 10 et al., 1998). The least squares objective function, or normalized root mean square error $\left(R M S E_{n}\right)$, is minimized to search for the optimal respiration model parameters $R_{\text {ref }}$ and $E_{0}$ :

$R M S E_{n}=\frac{\sqrt{\left(\sum\left(R_{e, \mathrm{sim}}-R_{e, \mathrm{obs}}\right)^{2}\right) / N}}{\overline{R_{e, \mathrm{obs}}}}$

where $R_{e, \text { sim }}$ is the simulated and $R_{e, \text { obs }}$ the observed $R_{e}, \overline{R_{e, \text { obs }}}$ the average observed $R_{e}$ and $N$ the number of observations. The observed respiration is the nighttime NEE.

Secondly the photosynthesis and transpiration module is optimized. This is a multi criteria problem and therefore the objective function consists of two parts. The normalized root mean square errors $\left(R M S E_{n}\right)$ of photosynthesis and transpiration are added up, giving equal weight to both processes:

\section{BGD}

6, 2863-2912, 2009

Seasonal variation in ecosystem

parameters derived from FLUXNET data

M. Groenendijk et al.

\section{Title Page}

Abstract

Introduction

Conclusions

References

Tables

Figures

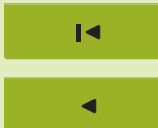

Back

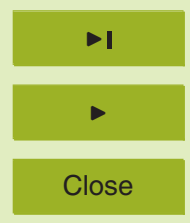

Full Screen / Esc

Printer-friendly Version

Interactive Discussion 
where $A_{\text {sim }}$ is simulated photosynthesis, $A_{\text {obs }}$ daytime GPP, $E_{\text {sim }}$ simulated transpiration and $E_{\text {obs }}$ observed transpiration. GPP is calculated as the difference between observed NEE and simulated $R_{e}$. Three parameters are used in the optimization, $J_{m}$, $\alpha$ and $\lambda$. All other parameters are kept constant as in Table 2. When these three pa-

5 rameters are being derived together, a global minimum of the objective function could not be found. Therefore the optimization is done in two steps. First the values of $J_{m}$ and $\alpha$ are determined. Here $\lambda$ is kept constant at an initial value. Secondly the value of $\lambda$ is determined by minimizing the objective function, when $J_{m}$ and $\alpha$ are kept constant. These two steps are repeated until all three parameters converge to a constant value, 10 which is very fast, because $J_{m}$ and $\alpha$ are only related to photosynthesis.

Weekly parameters are estimated with all observations within a week. Only for weeks with more than 30 half-hourly observations parameters are estimated. Gap-filled fluxes were not used, because we did not want to add uncertainties to the parameters due to gap-filling procedures.

\subsubsection{Parameter uncertainty}

Flux measurements have random and systematic sources of uncertainty. Systematic errors result from the equipment used and data processing procedures, such as inaccurate calibrations, high- and low-frequency flux losses. And random errors occur because of storage related problems during low turbulence conditions and advection and from the measurement instruments (Raupach et al., 2005; Richardson et al., 2008; Lasslop et al., 2008). Hollinger et al. (2004) use two closely located towers at Howland to estimate the random flux error, which is a substitute for various types of errors. From the differences between the half hourly fluxes at the two towers a standard deviation was calculated. This methodology can be applied to one tower as well, by replacing space by time (Hollinger and Richardson, 2005; Richardson et al., 2006). We estimated the flux data uncertainty of all sites by using this method of selecting paired observations representing the random flux error. We do not include the systematic error because there is no systematic general approach to derive this for all sites, although

BGD

6, 2863-2912, 2009

Seasonal variation in ecosystem

parameters derived from FLUXNET data

M. Groenendijk et al.

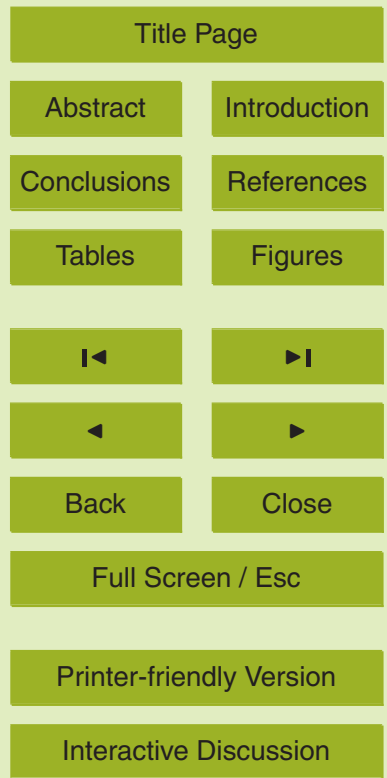


this will underestimate the flux uncertainty (Lasslop et al., 2008).

The criteria used for selecting the paired observations are that they have to occur in 2 subsequent days, at the same time of the day, under nearly identical environmental conditions (PAR within $75 \mu \mathrm{mol} \mathrm{m} \mathrm{m}^{-2} \mathrm{~s}^{-1}$, air temperature within $3^{\circ} \mathrm{C}$ and vapour 5 pressure deficit within $0.2 \mathrm{kPa}$ ). The difference between the paired observed fluxes is the random error and from all paired observation a frequency distribution of the flux uncertainty and a standard deviation is calculated.

The flux uncertainty is used to generate 500 randomly modified data sets for each site separately. First paired observations are selected, which are used to define a 10 polynomial relation between flux size and uncertainty. Secondly, each half hourly flux (average) is multiplied by this relation (standard deviation) and a random number from a normal distribution to generate 500 datasets. Thirdly, the model is optimized for all 500 datasets in a Monte Carlo simulation, which gives 500 parameters sets from which the parameter uncertainty is calculated.

\section{Results}

\subsection{Model quality and parameter uncertainty}

Three quality criteria are applied to select sites which will be used in the analysis. First simulated fluxes are compared with observations by a statistical t-test, which compares the distributions and means of two samples. Site years with a significance level of

$20 \quad p>0.05$ were removed. Secondly, site years with correlation coefficients $\left(r^{2}\right)$ below 0.2 were removed. Thirdly, site years with a parameter uncertainty above $10 \%$ were removed.

In Fig. 1 an example of the relation between flux size and uncertainty (dNEE and $\mathrm{d} L E$ ) is given for a pine forest (NL-Loo). As in Richardson et al. (2006) uncertainty increases with flux size. With these flux uncertainties the model parameter uncertainties were determined. This was only done for long term parameters, which represent all data years of each individual site, because of the very long computing time needed.

BGD

6, 2863-2912, 2009

Seasonal variation in ecosystem

parameters derived from FLUXNET data

M. Groenendijk et al.

Title Page

Abstract

Introduction

Conclusions

Tables

References

Figures

14

$\triangleleft$

$\rightarrow 1$

Back

Close

Full Screen / Esc

Printer-friendly Version

Interactive Discussion 
Only sites are selected with a parameter uncertainty below $10 \%$.

In Fig. 2 the initial distribution of site year $r^{2}$ values are compared with the values after removal of sites. The $r^{2}$ values are comparisons of half-hourly observations with simulations for each year at each site. From the initial 223 sites with 834 site years 5 there are now 121 sites with 377 site years left for further analysis. The distribution of $r^{2}$ is presented for the main vegetation types in Fig. 3. Nighttime NEE is poorly simulated for the evergreen broadleaf forests. For the other vegetation types the respiration simulations are very good, with a median $r^{2}$ of almost 0.9. NEE is simulated with almost similar quality for all vegetation types, with a median $r^{2}$ of around 0.6. Sim10 ulations of $L E$ are slightly better than of $N E E$, with the best simulations for grasslands with a median $r^{2}$ of almost 0.8 . The quality of the model is good enough to analyze the model parameters, only for the evergreen broadleaf forests we will need to be careful interpreting the model results.

\subsection{Seasonal variation}

15 In Fig. 4 to 8 we show the mean seasonal cycles of each of the five model parameters as a function of vegetation type and climate region (as in Table 1). For clarity reasons, we only show the three vegetation types and four climate regions containing the majority of the sites. $R_{\text {ref }}$ (Fig. 4) has a clear seasonal cycle, particularly for the colder climate regions. For Mediterranean sites there is almost no such variation between 20 seasons, or even a decrease of $R_{\text {ref }}$ during the dry summer. $E_{0}$ (Fig. 5) varies between $200 \mathrm{~K}$ and $350 \mathrm{~K}$, but does not show a seasonal pattern. The seasonal patterns of the respiration model parameters suggests that $E_{0}$ can be kept constant, and that $R_{\text {ref }}$ is (partly) a function of seasonal varying climate variables.

The photosynthesis and transpiration model parameters $J_{m}, \alpha$ and $1 / \lambda$ (Fig. 6 25 to 8 ) have a clear seasonality that is closely related to vegetation phenology. For Mediterranean PFTs $J_{m}$ has the most pronounced variation throughout the year. For Mediterranean broadleaf forests $\alpha$ and $1 / \lambda$ have some seasonal variation, whereas for Mediterranean needleleaf forests and grasslands $\alpha$ and $1 / \lambda$ are quite constant. For

\section{BGD}

6, 2863-2912, 2009

Seasonal variation in ecosystem

parameters derived from FLUXNET data

M. Groenendijk et al.

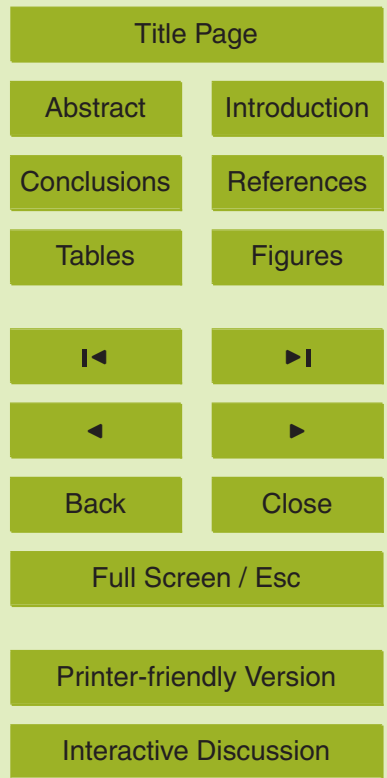


the colder climates $J_{m}$ of broadleaf forests have shorter growing seasons, but the $J_{m}$ summer maxima are similar for all climates. For needleleaf forests, $J_{m}$ shows less variation with growing season than broadleaf forests, but $J_{m}$ summer maxima are higher in warmer climates. For grasslands, $J_{m}$ shows a large variation with both growing season 5 length and summer maxima.

For all climate regions, $\alpha$ of broadleaf forests shows the clearest seasonality, with similar summer maxima of 0.4 to 0.5 . For evergreen needleleaf forests and grasslands $\alpha$ is less variable, with only clear seasonality for the colder regions. The warmest region does not have the highest values for $\alpha$, as was the case for $J_{m}$. This might be an indication that drought or high temperatures limits primarily $\alpha$.

For both broadleaf and needleleaf forests, temperate climates have higher summer maxima of water use efficiency $(1 / \lambda)$ than boreal and Mediterranean forests. For temperate continental forests, with warm summers, the efficiency is lower than in the temperate (maritime) forests. Grasslands are less water efficient than forests during the 15 entire year.

Overall the five parameters show seasonal variation for most vegetation types and climate regions, which we will try to relate to climate seasonality in the next section. General patterns that we observed are the relative constant $R_{\text {ref }}, \alpha$ and $1 / \lambda$ during the year for needleleaf forests and grasslands in warmer climates. Largest seasonal variation for all five parameters is seen at broadleaf forests in all climate regions. In boreal regions values of $R_{\text {ref }}, J_{m}, \alpha$ and $1 / \lambda$ are generally lower than in temperate regions for all vegetation types.

\subsection{Statistical analysis}

The seasonal patterns of the model parameters are very similar at first sight. To de-

fine how similar, a principal component analysis (PCA) is performed to determine the variance between model parameters. The parameters are replaced by components, of which the principal component gives a measure for the covariance between the parameters. For the PCA first the parameters are normalized. The correlation matrix is

Seasonal variation in ecosystem parameters derived from FLUXNET data

M. Groenendijk et al.

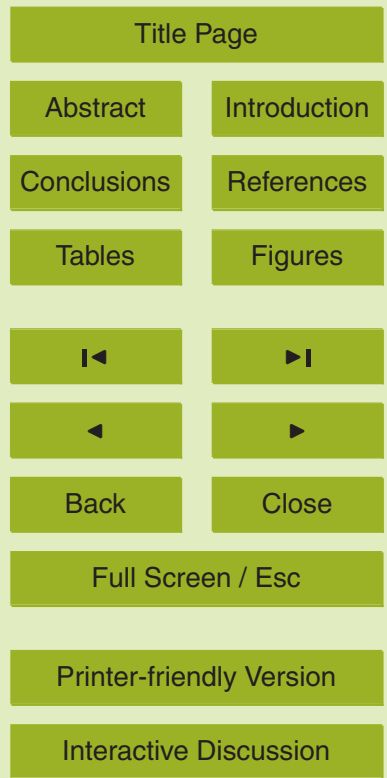


calculated from which the eigenvalues are determined representing the explained variance of the components. Within the eigenvector of each component the loadings give the weight of the parameters within the component.

First a PCA is performed for all five parameters. When all weekly parameters for all 5 sites are used it can be seen from Table 3 that the explained variation is $36.78 \%$ with the principal component. When the PCA is performed for sites within each vegetation type separately the explained variation is slightly higher, e.g., $44.71 \%$ for deciduous broadleaf forest and $41.14 \%$ for evergreen needleleaf forest. These values of 35 up to $45 \%$ of explained variation give the overlap in seasonal patterns and show that the 10 model is not over parameterized. The differences in loadings between vegetation types show that the variation in parameters is not equal. For example the loadings for $1 / \lambda$ are lower for closed shrubland, grassland and woody savanna, which indicates that these have a different behaviour than the other vegetation types.

The seasonal variation for the three parameters in the photosynthesis and transpi15 ration module is very similar (Fig. 6 to 8 ). Therefore a PCA is performed with these three parameters separately. In Table 4 can be seen that indeed the explained variance by the principal component for these three parameters is higher than for all five parameters combined. For parameters of one vegetation type the explained variance is $68.47 \%$ for deciduous broadleaf forest and $52.15 \%$ for evergreen needleleaf forest.

20 This high explained variance and similar loadings shows that these three parameters follow more similar patterns between vegetation types.

To test which climate variables are related to the model parameters we performed a stepwise multiple regression with air temperature, precipitation, global radiation, vapour pressure deficit (VPD), and soil water content (SWC) (Table 5). The performance of 25 the regression models is very poor, with correlation coefficients below 0.1 when using model parameters of all sites lumped together. When sites are grouped into vegetation classes the model performs somewhat better. Overall the temperature seems to be the climate variable that explains most of the parameter variation.

Only for the deciduous broadleaf forests is there statistical evidence that the photo2876

BGD

6, 2863-2912, 2009

Seasonal variation in ecosystem

parameters derived from FLUXNET data

M. Groenendijk et al.

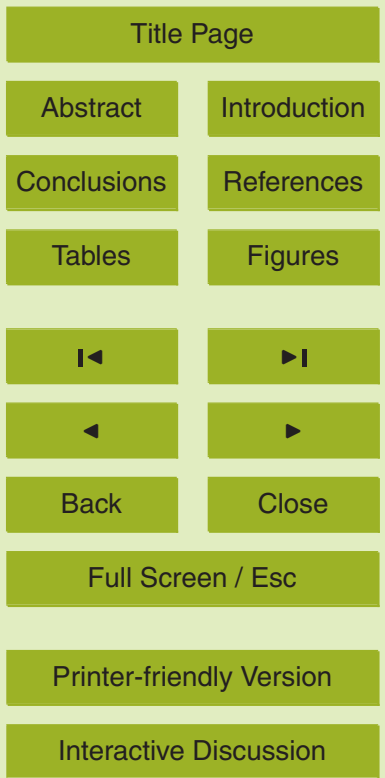


synthesis parameters can be explained linearly with climate variables, and temperature is the most important determinant. Most likely the poor result for the other vegetation types is a result of the fact that the relations between climate variables and model parameters are not linear. This supports the idea that a complex model is needed to

\section{Discussion}

We used a simple vegetation model (5PM) to study the variability of the parameters. A weekly parameter time step length was chosen, because this is the scale on which plants respond to weather variations by regulation through changes in vegetation characteristics. Several motivations for the choice for weekly model parameters can be given. First of all, by using much longer times steps we hinder the model to capture the seasonality of the carbon and water fluxes. Seasonal variation of model parameters is needed because the original models of Cowan (1977), Cowan and Farquhar (1977) and Farquhar et al. (1980) were developed to simulate the variation of leaf level photosynthesis and transpiration on a daily time scale. Upscaling is needed to apply the model on the ecosystem level and on longer time scales. In this study, the derivation of seasonally varying model parameters can be considered as such an upscaling exercise.

There is some debate as to which level LAI may predict model parameters. Lindroth 20 et al. (2008) suggest that model parameters scale with LAI for northern European forests. However, Kolari et al. (2007) report that the photosynthetic efficiency of shoots, without influence of amount of needles, show seasonality, following the mean daily temperature with a delay. Wilson et al. (2001) shows similar results for deciduous trees. This supports that the parameters are valuable to study the processes on this scale.

We did not use LAl as a model parameter, primarily because LAI measurements were insufficiently available for the majority of the sites. Distributing the FLUXNET sites into classes of PFT and climate zone probably removes the largest variability within groups. Omitting LAI as a model parameter may limit the predictive skills of the model when

BGD

6, 2863-2912, 2009

Seasonal variation in ecosystem

parameters derived from FLUXNET data

M. Groenendijk et al.

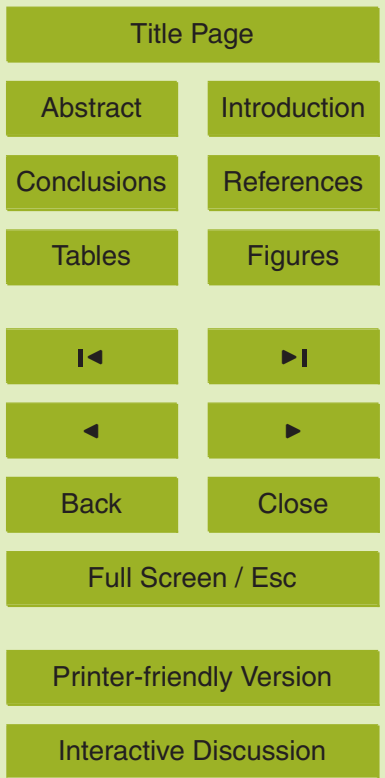


vegetation adapts by growing extra leafs. However the effects of LAI are represented within the model parameters, implicitly accounting for variation in LAI.

The importance of seasonality of model parameters for improvement of carbon flux simulations is already suggested in different studies. Wang et al. (2003) show sea5 sonal photosynthesis parameters for both coniferous and deciduous temperate forests derived form eddy covariance data. Wang et al. (2007) show that seasonal variation is related to leaf phenology for three deciduous forests and one savanna site and also to soil water and temperature for a tree-grass savanna site. For evergreen needleleaf forests no seasonality was observed in parameter values in this study. Wilson et al. 10 (2001) observed that at the leaf level there is also an almost similar seasonality for different tree species, which they related to leaf age. We observed similar seasonality for photosynthesis parameters, $J_{m}$ and $\alpha$ in Figs. 6 and 7, with maximum values during summer. For needleleaf forests we found not as much seasonality as for deciduous broadleaf forests.

15 The use of the intrinsic water use efficiency $(\lambda)$ to describe the relation between ecosystem carbon production and water use is not used is many studies. Our model results are similar as the model of Ball et al. (1987) and Leuning (1995), but our model has the advantage that fewer parameters need to be fitted. $\lambda$ gives new insights in the adaptation of vegetation to weather seasonality (Schymanski et al., 2007). A general finding from our study is that $1 / \lambda$ is highest, or water use is most efficient, during the warmer summer months. This seems to be opposite as found by Schymanski et al. (2007), who stated that vegetation was less water use efficient during the dry season. van der Tol et al. (2007) also found high values of $1 / \lambda$ for Mediterranean deciduous forest sites with low water availability, supporting our results. From Fig. 8 we see that the subtropical-Mediterranean and boreal needleleaf forests have lower values for $1 / \lambda$ in summer than temperate needleleaf forests. But for broadleaf forests this is not observed. Because we did not find a clear relation with soil water content, as proposed by Cowan (1982), it is still unclear what the relation between $1 / \lambda$ and the climate variables is. It is clear that more research is needed to fully understand the

Seasonal variation in ecosystem parameters derived from FLUXNET data

M. Groenendijk et al.

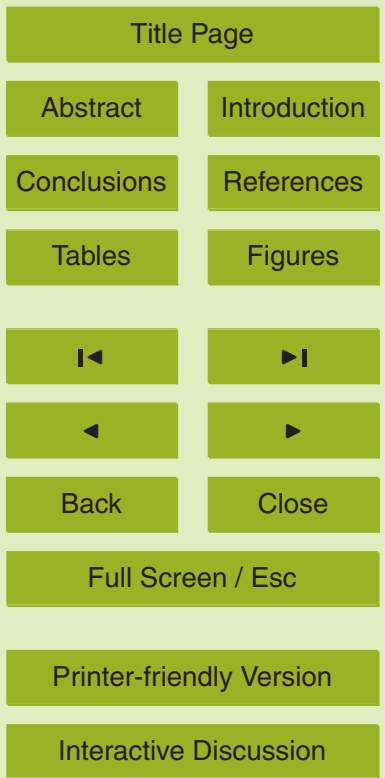


variation of this parameter, as this optimality hypothesis is already developed in 1977 , but only recently being applied for different regions.

It is tempting to linearly relate the seasonal variation of model parameters with plant phenology and weather variations, but it remains challenging to unravel the precise

5 dependencies, as consequences often follow some time after the cause. We could not find well-defined relations between the parameters and climate variables. For example the parameter describing maximum electron transport $\left(J_{m}\right)$, used in the function to simulate photosynthesis, does not show a well defined relation with air temperature, global radiation, vapour pressure deficit and soil water content. We hypothesize that ${ }_{10} J_{m}$ is more sensitive to climate variables in spring and autumn than in the summer and we intend to study such seasonally varying dependencies in a follow-on paper.

We hypothesize that the absence of well-defined relations between model parameters and climate is because different climate variables influence the parameter values or vegetation characteristics during different stages of phenology. This is supported by 15 results from Thum et al. (2008) where $J_{m}$ and $V_{c m}$ are described with an exponential temperature function for four boreal needleleaf forests. Up to four different fits were needed to describe this seasonal variation, which shows that temperature responses are variable through the year, and not one parameter can be related to climate variables with a single annual fit. This explains why we found very poor relations between weekly model parameters and climate in the multiple regression analysis. This also implies that it is not sensible to relate the annual mean $J_{m}$ with annual mean climate.

\section{Conclusions}

For understanding the global variation in carbon and water balances and predicting the ecosystem sensitivities to climate it is important to identify the processes driving the

differences. In this study a methodology is presented using FLUXNET data and vegetation model (5PM) to obtain seasonally varying model parameters. Two parameters $\left(R_{\text {ref }}\right.$ and $\left.E_{0}\right)$ are related to ecosystem respiration and three parameters $\left(J_{m}, \lambda\right.$ and $\left.\alpha\right)$ to photosynthesis and transpiration. These model parameters are a resultant of the

Seasonal variation in ecosystem parameters derived from FLUXNET data

M. Groenendijk et al.

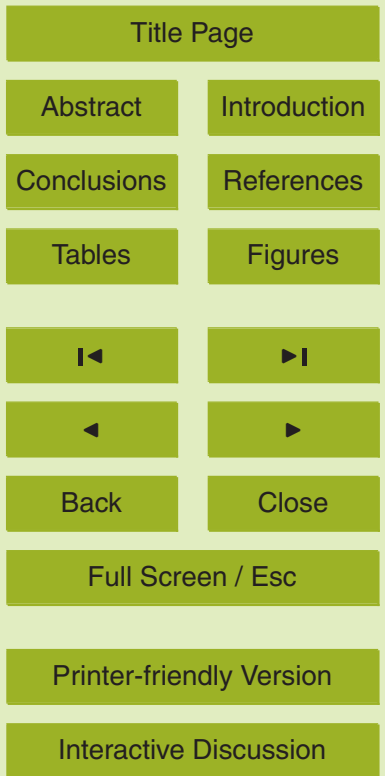


interaction between both climate and vegetation and therefore very valuable to study ecosystem sensitivities to climate.

The quality of the simulated half hourly carbon and water fluxes is good for 121 sites, with a correlation coefficient between 0.5 and 0.8 and a model parameter uncertainty 5 below $10 \%$. This shows that the 5PM model can be applied globally for sites in all vegetation and climate classes. Only for evergreen broadleaf forests the respiration simulations have a poor quality, which means that we need to be careful when interpreting these results.

The fact that neither carbon fluxes nor model parameters are linearly related to cli10 mate shows that more complex models, like 5PM, are needed to investigate the change of carbon fluxes related to climate.

The variation of weekly model parameters is large between PFTs, which allows to study the differences in ecosystem characteristics. General patterns that we observed are the relative constant $R_{\text {ref }}, \alpha$ and $\lambda$ during the year for needleleaf forests and grass15 lands in warmer climates. Largest seasonal variation for all five parameters is seen at broadleaf forests in all climate regions. In boreal regions values of $R_{\text {ref }}, J_{m}, \alpha$ and $1 / \lambda$ are always lower than in temperate regions for all vegetation types. When seasonality of the model parameters is large, there is a strong relation between vegetation and climate. This suggests that climate change will have the largest impact on the terrestrial carbon fluxes in boreal regions and for deciduous forests, and less for grasslands and evergreen forests.

We started the introduction by describing the use of PFTs in climate models. The question is now how our results may be used to better quantify model parameters, as a function of climate. We found quit large differences between the PFTs, but this may be an artifact of looking at averages, and it cannot be ruled out that model parameters change gradually between PFTs. We intend to study this in a follow-on publication. The key question is what causes variations in model parameters.

Seasonal variation in ecosystem parameters derived from FLUXNET data

M. Groenendijk et al.

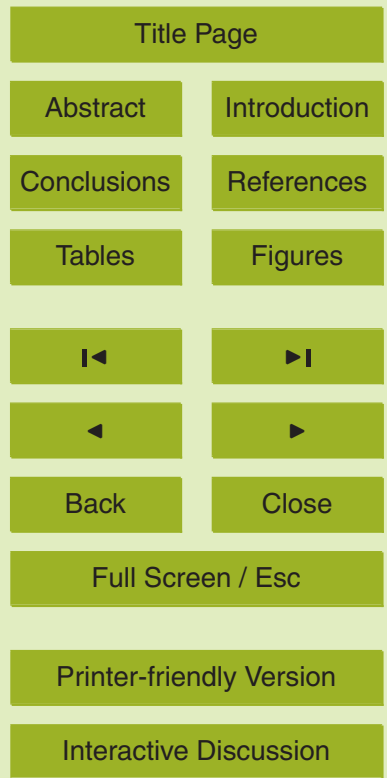




\section{Appendix A}

\section{PM model description}

Transpiration $\left(L E, \mathrm{~W} \mathrm{~m}^{-2}\right)$ is a function of stomatal conductance $\left(g_{s}, \mathrm{~m} \mathrm{~s}^{-1}\right)$ and the 5 gradient of the $\mathrm{H}_{2} \mathrm{O}$ concentration between vegetation and air:

$L E=1.6 D g_{s}$

where $D$ is the molar vapor gradient between stomata and the air $\left(\mathrm{mol} \mathrm{m}^{-3}\right)$ and 1.6 the ratio of molecular diffusivity of $\mathrm{H}_{2} \mathrm{O}$ to $\mathrm{CO}_{2}$. Photosynthesis or $\mathrm{CO}_{2}$ assimilation $(A$, $\mu \mathrm{mol} \mathrm{m} \mathrm{m}^{-2} \mathrm{~s}^{-1}$ ) is a function of $g_{s}$ as well:

$10 \quad A=g_{s}\left(\mathrm{C}_{a}-\mathrm{C}_{i}\right)$

where $\mathrm{C}_{a}$ is the $\mathrm{CO}_{2}$ concentration in the air and $\mathrm{C}_{i}$ the internal $\mathrm{CO}_{2}$ concentration (ppm). To obtain $g_{s}$, first photosynthesis $(A)$ is determined as in Farquhar et al. (1980). Photosynthesis is the minimum of carboxylation $\left(W_{c}\right)$, which is enzyme limited, and RuBP regeneration $\left(W_{j}\right)$, which is light limited.

$15 \quad A=\left(1-\Gamma^{*} / \mathrm{C}_{i}\right) \min \left\{W_{c}, W_{j}\right\}$

where $\Gamma^{*}$ (bar) is the compensation point for $\mathrm{CO}_{2}$ in absence of dark respiration. Dark respiration is not included in this equation, because it is already simulated within the ecosystem respiration as described in the previous section. $W_{c}$ and $W_{j}$ are determined with the following equations (Farquhar et al., 1980; von Caemmerer and Farquhar, 1981; Harbinson et al., 1990):

$W_{c}=\frac{V_{c m} \mathrm{C}_{i}}{\mathrm{C}_{i}+k^{\prime}}$

$W_{j}=\frac{J C_{i}}{4\left(C_{i}+2 \Gamma^{*}\right)}$

Seasonal variation in ecosystem parameters derived from FLUXNET data

M. Groenendijk et al.

Title Page

Abstract Introduction

Conclusions

Tables References Figures

14

4

Back

Full Screen / Esc

Printer-friendly Version

Interactive Discussion 
$k^{\prime}=K_{c}\left(1+O / K_{o}\right)$

$\Gamma^{*}=0.5 \frac{V_{o m}}{V_{c m}} \frac{K_{c}}{K_{o} O}$

$J=\frac{\alpha /_{\mathrm{PAR}} J_{m}}{\alpha I_{\mathrm{PAR}}+2.1 J_{m}}$

where $/_{\text {PAR }}$ is the photosynthetic active radiation ( $\mu$ mol photons $\mathrm{m}^{-2} \mathrm{~s}^{-1}$ ), $J$ the electron 5 yield, $V_{c m}$ the maximum carboxylation capacity $\left(\mu \mathrm{molm}^{-2} \mathrm{~s}^{-1}\right), V_{o m}$ the maximum rate of oxygenation of Rubisco $\left(\mu \mathrm{mol} \mathrm{m}{ }^{-2} \mathrm{~s}^{-1}\right), J_{m}$ the maximum potential electron transport rate $\left(\mu \mathrm{mol} \mathrm{m}^{-2} \mathrm{~s}^{-1}\right), \alpha$ the quantum yield or light use efficiency $\left(\mathrm{mol} \mathrm{mol}^{-1}\right), K_{c}$ the kinetic coefficient for $\mathrm{CO}_{2}$ (bar), $K_{o}$ the kinetic coefficient for $\mathrm{O}_{2}$ (bar) and $\mathrm{O}$ the $\mathrm{O}_{2}$ concentration (bar). $K_{c}$ and $K_{o}$ are corrected for temperature with an Arrhenius function. $C_{i}$ 10 is calculated as described in Arneth et al. (2002), where the models of Cowan (1977) and Farquhar et al. (1980) are combined, by solving the following quadratic equation:

$k_{2} \mathrm{C}_{i}^{2}+k_{1} \mathrm{C}_{i}+k_{0}=0$

There are 2 sets of solutions for the $k$ parameters, under enzyme limited conditions $\left(W_{c}\right)$ and light limited conditions $\left(W_{j}\right)$. In the enzyme limited case the values for the $k$ 15 parameters are calculated with the following equations:

$k_{2}=\lambda-\frac{1.6 D}{k^{\prime}+\Gamma^{*}}$

$k_{1}=1.6 D-2 \lambda C_{a}+\frac{1.6 D\left(\Gamma^{*}-k^{\prime}\right)}{k^{\prime}+\Gamma^{*}}$

$k_{0}=\left(\lambda C_{a}-1.6 D\right) C_{a}+\frac{1.6 D \Gamma^{*} k^{\prime}}{k^{\prime}+\Gamma^{*}}$

And in the light limited case by:

Seasonal variation in ecosystem

parameters derived from FLUXNET data

M. Groenendijk et al.

\section{Title Page}

Abstract

Conclusions

Tables

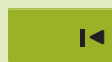

14

4

Back

Full Screen / Esc

Printer-friendly Version

Interactive Discussion 
$k_{2}=\lambda-\frac{1.6 D}{3 \Gamma^{*}}$

$k_{1}=1.6 D-2 \lambda C_{a}+\frac{1.6 D \Gamma^{*}}{3 \Gamma^{*}}$

$k_{0}=\left(\lambda C_{a}-1.6 D\right) C_{a}+\frac{1.6 D 2 \Gamma^{* 2}}{3 \Gamma^{*}}$

where $\mathrm{C}_{a}$ is the $\mathrm{CO}_{2}$ concentration in the air (bar), $D$ the air saturation deficit (bar) and ${ }_{5} \lambda$ the intrinsic water use efficiency $\left(\mathrm{mol} \mathrm{mol}^{-1}\right)$.

\section{Appendix B}

\section{FLUXNET sites}

Acknowledgements. The authors gratefully acknowledge the collection of the FLUXNET 10 database by all people involved, especially the following site researchers: Alan Barr, Alessandro Araujo, Alessandro Peressotti, Allen Goldstein, Almut Arneth, Anders Lindroth, Andrej Varlagin, Andy Black, Axel Don, Bert Drake, Bev Law, Bill Munger, Bruce Cook, Brian Amiro, Carl Bernacchi, Casimiro Pio, Christian Bernhofer, Christof Ammann, Corinna Rebmann, Damiano Gianelle, Dan Ricciuto, Dan Yakir, Danilo Dragoni, Dario Papale, Dave Hollinger, Denis Loustau, Dennis Baldocchi, Donatella Spano, Ebba Dellwik, Eddy Moors, Enzo Magliulo, Francesco Vaccari, Franco Miglietta, Gabriel Pita, Gerard Kiely, Giorgio Matteucci, H. Thorgeirsson, Hank A. Margolis, Harry McCaughey, Humberto da Rocha, Jason Beringer, Jean-François Soussana, Jean-Marc Bonnefond, Jim Randerson, Jiquan Chen, Joao Pereira, John Moncrieff, Ken Davis, Kentaro Takagi, Lawrence B. Flanagan, Leonardo Montagnani, Lianhong Gu, M. Altaf Arain, Ma 20 Teresa Sebastiá, Marc Aubinet, Marcy Litvak Margaret Torn, Maria Jose Sanz, Mike Goulden, Nobuko Saigusa, Olivier Roupsard, Paul di Tomassi, Peter Curtis, Peter Lafleur, Pierre Cellier, Ray Leuning, Roser Matamala, Russ Monson, Russell Scott, Ryuichi Hirata, Scott Saleska, Serge Rambal, Shashi Verma, Shiping Chen, Thomas Foken, Tilden Meyers, Tim Martin, Timo

Seasonal variation in ecosystem

parameters derived from FLUXNET data

M. Groenendijk et al.

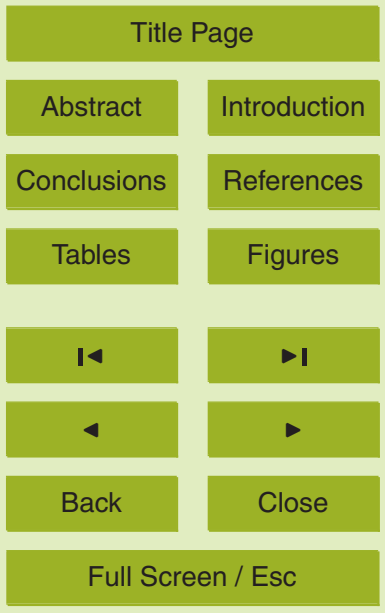

Printer-friendly Version

Interactive Discussion 
Vesala, Tomomichi Kato, Tuomas Laurila, Vincenzo Magliulo, Walt Oechel, Werner Kutsch and Zoltan Tuba. Without this global data this research would not have been possible.

This work is the outcome of the La Thuile FLUXNET workshop 2007, which received financial support of CarboEuropeIP, FAO-GTOS-TCO, iLEAPS, Max Planck Institute for Biogeochem-

5 istry, National Science Foundation, University of Tuscia, US Department of Energy. We acknowledge database and technical support from Berkeley Water Center, Lawrence Berkeley National Laboratory, Microsoft Research eScience, Oak Ridge National Laboratory, University of California - Berkeley, University of Virginia. The following networks participated with flux data: AmeriFlux, AfriFlux, AsiaFlux, CarboAfrica, CarboEuropelP, ChinaFlux, Fluxnet-Canada, KoFlux, LBA, NECC, OzFlux, TCOS-Siberia, USCCC. B. E. Law is acknowledged for her work on the AmeriFlux database as part of the AmeriFlux Science Team Research grant (US Department of Energy, Terrestrial Carbon program Award DE-FG02-04ER63911).

We want to thank Christiaan van der Tol for discussion about and help with the model development. This research is funded by a grant from the Netherlands Organization for Scientific 15 Research (NWO).

\section{References}

Amiro, B., Orchansky, A., Barr, A., Black, T., Chambers, S., III, F. C., Goulden, M., Litvak, M., Liu, H., McCaughey, J., McMillan, A., and Randerson, J.: The effect of post-fire stand age on the boreal forest energy balance, Agr. Forest. Meteorol., 140, 41-50, doi:10.1016/j. agrformet.2006.02.014, 2006. 2902

Anthoni, P. M., Knohl, A., Rebmann, C., Freibauer, A., Mund, M., Ziegler, W., Kolle, O., and Schulze, E.-D.: Forest and agricultural land-use-dependent $\mathrm{CO}_{2}$ exchange in Thuringia, Germany, Glob. Change Biol., 10, 2005-2019, 2004. 2903

Arneth, A., Lloyd, J., Šantrǔčková, H., Bird, M., Grigoryev, S., Kalaschnikov, Y. N., Gleixner, $25 \quad$ G., and Schulze, E.-D.: Response of central Siberian Scots pine to soil water deficit and long-term trends in atmospheric $\mathrm{CO}_{2}$ concentration, Global Biogeochem. Cy., 16, 1005, doi: 10.1029/2000GB001374,2002, 2002. 2882

Aurela, M., Laurila, T., and Tuovinen, J.-P.: Seasonal $\mathrm{CO}_{2}$ balances of a subarctic mire, J. Geophys. Res., 106, 1623-1637, 2001. 2903

BGD

6, 2863-2912, 2009

Seasonal variation in ecosystem

parameters derived from FLUXNET data

M. Groenendijk et al.

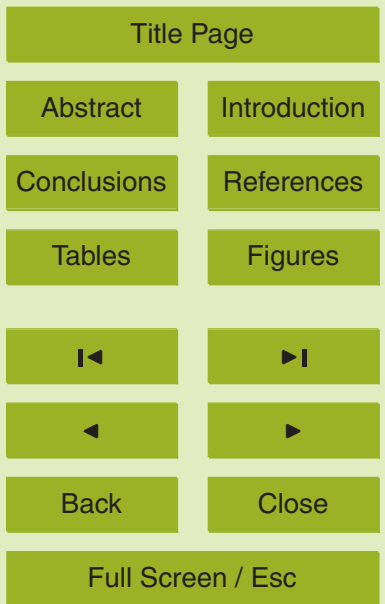

Printer-friendly Version

Interactive Discussion 
Baldocchi, D.: TURNER REVIEW No. 15. Breathing of the terrestrial biosphere: lessons learned from a global network of carbon dioxide flux measurement systems, Aust. J. Bot., 56, 1-26, doi:10.1071/BT07151, 2008. 2865, 2870

Baldocchi, D., Falge, E., Gu, L., Olson, R., Hollinger, D., Running, S., Anthoni, P., Bernhofer, C.,

5 Davis, K., Evans, R., Fuentes, J., Goldstein, A., Katul, G., Law, B., Lee, X., Mahli, Y., Meyers, T., Munger, W., Oechel, W., Paw, K. T., Pilegaard, K., Schmid, H. P., Valentini, R., Verma, S., Vesala, T., Wilson, K., and Wofsy, S.: FLUXNET: A new tool to study the temporal and spatial variability of ecosystem-scale carbon dioxide, water vapor, and energy flux densities, B. Am. Meteorol. Soc., 82, 2415-2434, doi:10.1175/1520-0477(2001)082(2415:FANTTS)2.3.CO;2, 2001. 2870

Baldocchi, D. D., Xu, L., and Kiang, N.: How plant functional-type, weather, seasonal drought, and soil physical properties alter water and energy fluxes of an oak-grass savanna and an annual grassland, Agr. Forest. Meteorol., 123, 13-39, 2004. 2904

Ball, J. T., Woodrow, I. W., and Berry, J. A.: A Model Predicting Stomatal Conductance and its Contribution to the Control of Photosynthesis under Different Environmental Conditions, in: Progress in Photosynthetic Research, edited by: Biggins, J., vol. IV, pp. 221-224, Martinus Nijhoff, Dordrecht, The Netherlands, 1987. 2878

Berbigier, P., Bonnefond, J.-M., and Mellmann, P.: $\mathrm{CO}_{2}$ and water vapour fluxes for 2 years above Euroflux forest site, Agr. Forest Meteorol., 108, 183-197, doi:10.1016/ 20 S0168-1923(01)00240-4, 2001. 2903

Beringer, J., Hutley, L. B., Tapper, N. J., and Cernusak, L. A.: Savanna fires and their impact on net ecosystem productivity in North Australia, Glob. Change Biol., 13, 990-1004, doi: 10.1111/j.1365-2486.2007.01334.x, 2007. 2902

Chen, J. M., Govind, A., Sonnentag, O., Zhang, Y., Barr, A., and Amiro, B.: Leaf area index measurements at Fluxnet-Canada forest sites, Agr. Forest Meteorol., 140, 257-268, doi: 10.1016/j.agrformet.2006.08.005, 2006. 2902

Cook, B. D., Davis, K. J., Wang, W., Desai, A., Berger, B. W., Teclaw, R. M., Martin, J. G., Bolstad, P. V., Bakwin, P. S., Yi, C., and Heilman, W.: Carbon exchange and venting anomalies in an upland deciduous forest in northern Wisconsin, USA, Agr. Forest Meteorol., 126, $30 \quad$ 271-295, doi:10.1016/j.agrformet.2004.06.008, 2004. 2904

Corradi, C., Kolle, O., Walter, K., Zimov, S. A., and Schulze, E.-D.: Carbon dioxide and methane exchange of a north-east Siberian tussock tundra, Glob. Change Biol., 11, 1910-1925, doi: 10.1111/j.1365-2486.2005.01023.x, 2005. 2904

BGD

6, 2863-2912, 2009

Seasonal variation in ecosystem

parameters derived from FLUXNET data

M. Groenendijk et al.

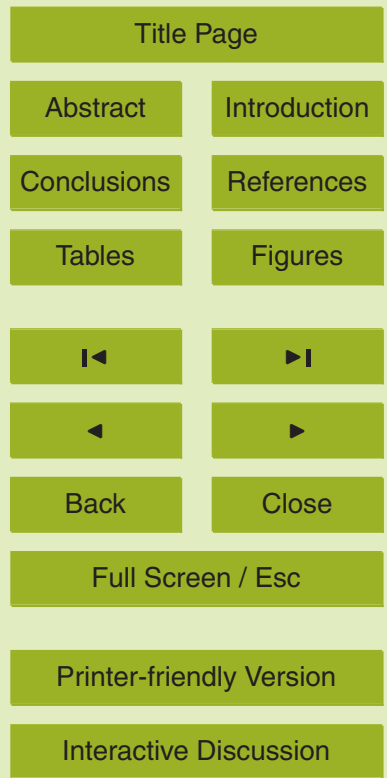


Costa, M. and Foley, J.: Trends in the hydrological cycle of the Amazon basin, J. Geophys. Res., D104, 14189-14198, 1999. 2865

Cowan, I. R.: Stomatal behaviour and environment, Adv. Bot. Res., 4, 117-228, 1977. 2869, 2877, 2882

5 Cowan, I. R.: Physical Plant Ecology II, chap. Regulation of water use in relation to carbon gain in higher plants, 589-613, Berlin, Springer, 1982. 2878

Cowan, I. R. and Farquhar, G. D.: Integration of activity in the higher plant, chap. Stomatal function in relation to leaf metabolism and environment, 471-505, Cambridge University Press, 1977. 2877

10 David, T. S., Ferreira, M. I., Cohen, S., Pereira, J. S., and David, J. S.: Constraints on transpiration from an evergreen oak tree in southern Portugal, Agr. Forest Meteorol., 122, 193-205, doi:10.1016/j.agrformet.2003.09.014, 2004. 2904

Davis, K. J., Bakwin, P. S., Yi, C., Berger, B. W., Zhao, C., Teclaw, R. M., and Isebrands, J. G.: The annual cycles of $\mathrm{CO}_{2}$ and $\mathrm{H}_{2} \mathrm{O}$ exchange over a northern mixed forest as observed from a very tall tower, Glob. Change Biol., 9, 1278-1293, doi:10.1046/j.1365-2486.2003.00672.x, 2003. 2904

Dickinson, R. E., Sellers, A. H., Kennedy, P. J., and Wilson, M. F.: Biosphere atmosphere transfer scheme (BATS) for the NCAR community climate model, NCAR technical note, TN275+STR, 69 pp., 1986. 2865

Dolman, A. J., Moors, E. J., and Elbers, J. A.: Characteristics of the carbon uptake of a mid latitude forest on sandy soil, Agr. Forest Meteorol., 111, 157-170, 2002. 2903

Dunn, A. L., Barford, C. C., WOFSY, S. C., Goulden, M. L., and Daube, B. C.: A long-term record of carbon exchange in a boreal black spruce forest: means, responses to interannual variability, and decadal trends, Glob. Change Biol., 13, 577-590, doi:10.1111/j.1365-2486. 2006.01221.x, 2007. 2902

Eltahir, E. and Bras, R.: Precipitation recycling, Rev. Geophys., 34, 367-378, 1996. 2865

Falge, E., Tenhunen, J., Baldocchi, D., Aubinet, M., Bakwin, P., Berbigier, P., Bernhofer, C., Bonnefond, J. M., Burba, G., Clement, R., Davis, K. J., Elbers, J. A., Falk, M., Goldstein, A. H., Grelle, A., Granier, A., Grunwald, T., Gudmundsson, J., Hollinger, D., Janssens, I. A., Keronen, P., Kowalski, A. S., Katul, G., Law, B. E., Mahli, Y., Meyers, T., Monson, R. K., Moors, E., Munger, J. W., Oechel, W., Paw, K. T., Pilegaard, K., Rannik, Ü., Rebmann, C., Suyker, A., Thorgeirsson, H., Tirone, G., Turnipseed, A., Wilson, K., and Wofsy, S.: Phase and amplitude of ecosystem carbon release and uptake potentials as derived from FLUXNET

BGD

6, 2863-2912, 2009

Seasonal variation in ecosystem

parameters derived

from FLUXNET data

M. Groenendijk et al.

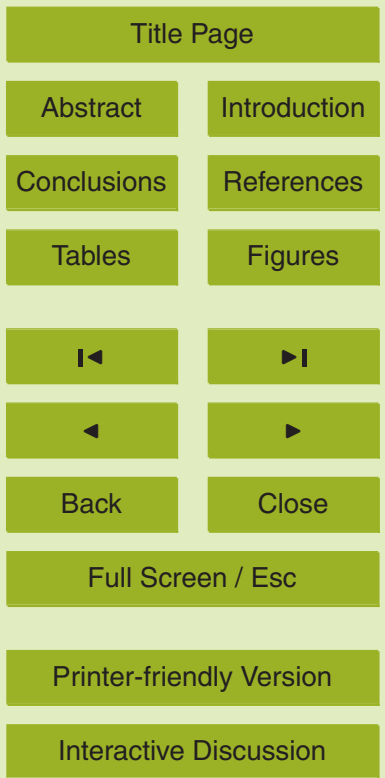

2886 
measurements, Agr. Forest Meteorol., 113, 53-74, doi:10.1016/S0168-1923(02)00103-X, 2002. 2865

Farquhar, G. D., von Caemmerer, S., and Berry, J. A.: A biochemical model of photosynthetic $\mathrm{CO}_{2}$ assimilation in leaves of C3 species, Planta, 149, 78-90, 1980. 2877, 2881, 2882

5 Feigenwinter, C., Bernhofer, C., and Vogt, R.: The influence of advection on the short term $\mathrm{CO}_{2}-$ budget in and above a forest canopy, Bound.-Lay. Meteorol., 113, 201-224, doi:10.1023/B: BOUN.0000039372.86053.ff, 2004. 2903

Fischer, M. L., Billesbach, D. P., Berry, J. A., Riley, W. J., and Torn, M. S.: Spatiotemporal variations in growing season exchanges of $\mathrm{CO}_{2}, \mathrm{H}_{2} \mathrm{O}$ and sensible heat in agricultural fields 10 in the southern great plains, Earth Interactions, 11, 17, doi:10.1175/EI231.1, 2007. 2904

Flanagan, L. B., Wever, L. A., and Carlson, P. J.: Seasonal and interannual variation in carbon dioxide exchange and carbon balance in a northern temperate grassland, Glob. Change Biol., 8, 599-615, doi:10.1046/j.1365-2486.2002.00491.x, 2002. 2902

Foley, J. A., Levis, S., Prentice, I. C., Pollard, D., and Thompson, S. L.: Coupling dynamic 15 models of climate and vegetation, Glob. Change Biol., 4, 561-579, doi:10.1046/j.1365-2486. 1998.t01-1-00168.x, 1998. 2865

Friend, A. D. and Cox, P. M.: Modelling the effects of atmospheric $\mathrm{CO}_{2}$ on vegetationatmosphere interactions, Agr. Forest Meteorol., 73, 285-295, doi:10.1016/0168-1923(94) 05079-L, 1995. 2865

20 Gholz, H. L. and Clark, K. L.: Energy exchange across a chronosequence of slash pine forests in Florida, Agr. Forest Meteorol., 112, 87-102, doi:10.1016/S0168-1923(02)00059-X, 2002. 2904

Giasson, M.-A., Coursolle, C., and Margolis, H. A.: Ecosystem-level $\mathrm{CO}_{2}$ fluxes from a boreal cutover in eastern Canada before and after scarification, Agr. Forest Meteorol., 140, 23-40, doi:10.1016/j.agrformet.2006.08.001, 2006. 2902

Gilmanov, T., Soussana, J., Aires, L., Allard, V., Ammann, C., Balzarolo, M., Barcza, Z., Bernhofer, C., Campbell, C., Cernusca, A., Cescatti, A., Clifton-Brown, J., Dirks, B., Dore, S., Eugster, W., Fuhrer, J., Gimeno, C., Gruenwald, T., Haszpra, L., Hensen, A., Ibrom, A., Jacobs, A., Jones, M., Lanigan, G., Laurila, T., Lohila, A., G.Manca, Marcolla, B., Nagy, Z., Pilegaard, K., Pinter, K., Pio, C., Raschi, A., Rogiers, N., Sanz, M., Stefani, P., Sutton, M., Tuba, Z., Valentini, R., Williams, M., and Wohlfahrt, G.: Partitioning European grassland net ecosystem $\mathrm{CO}_{2}$ exchange into gross primary productivity and ecosystem respiration using light response function analysis, Agr. Ecosyst. Environ., 121, 93-120, doi:

BGD

6, 2863-2912, 2009

Seasonal variation in ecosystem

parameters derived

from FLUXNET data

M. Groenendijk et al.

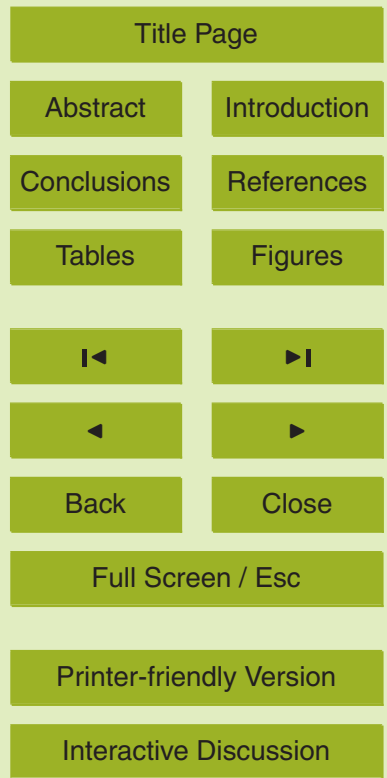


10.1016/j.agee.2006.12.008, 2007. 2903, 2904

Gilmanov, T. G., Tieszen, L. L., Wylie, B. K., Flanagan, L. B., Frank, A. B., Haferkamp, M. R., Meyers, T. P., and Morgan, J. A.: Integration of $\mathrm{CO}_{2}$ flux and remotely-sensed data for primary production and ecosystem respiration analyses in the Northern Great Plains: potential for quantitative spatial extrapolation, Global Ecol. Biogeogr., 4, 271-292, doi: 10.1111/j.1466-822X.2005.00151.x, 2005. 2904

Gough, C., Vogel, C., Schmid, H., Su, H.-B., and Curtis, P.: Multi-year convergence of biometric and meteorological estimates of forest carbon storage, Agr. Forest Meteorol., 148, 158-170, doi:10.1016/j.agrformet.2007.08.004, 2008. 2904

10 Goulden, M. L., Winston, G. C., McMillan, A. M. S., Litvak, M. E., Read, E. L., Rocha, A. V., and Elliot, J. R.: An eddy covariance mesonet to measure the effect of forest age on landatmosphere exchange, Glob. Change Biol., 12, 2146-2162, doi:10.1111/j.1365-2486.2006. 01251.x, 2006. 2902

Gu, L., Falge, E. M., Boden, T., Baldocchi, D. D., Black, T. A., Saleska, S. R., Suni, T., Verma, 15 S. B., Vesala, T., Wofsky, S. C., and Xu, L.: Objective threshold determination for nighttime eddy flux filtering, Agr. Forest Meteorol., 128, 179-197, 2005. 2870

Gu, L., Meyers, T., Pallardy, S. G., Hanson, P. J., Yang, B., Heuer, M., Hosman, K. P., Riggs, J. S., Sluss, D., and Wullschleger, S. D.: Direct and indirect effects of atmospheric conditions and soil moisture on surface energy partitioning revealed by a prolonged drought at a temperate forest site, J. Geophys. Res., 111, D16102, doi:10.1029/2006JD007161, 2006. 2904

Hahmann, A. and Dickinson, R.: RCCM2-BATS model over tropical South America: applications to tropical deforestation, J. Climate, 10, 1944-1964, 1997. 2865

Harbinson, J., Genty, B., and Baker, N. R.: The relationship between $\mathrm{CO}_{2}$ assimilation and electron transport in leaves, Photosynth. Res., 25, 213-224, 1990. 2881

Heinsch, F. A., Heilman, J. L., Mclnnes, K. J., Cobos, D. R., Zuberer, D. A., and Roelke, D. L.: Carbon dioxide exchange in a high marsh on the Texas Gulf Coast: effects of freshwater availability, Agr. Forest Meteorol., 125, 159-172, doi:10.1016/j.agrformet.2004.02.007, 2004. 2904

30 Hibbard, K. A., Law, B. E., Reichstein, M., and Sulzman, J.: An analysis of soil respiration across northern hemisphere temperate ecosystems, Biogeochemistry, 73, 29-70, doi:10. 1007/s10533-004-2946-0, 2005. 2904

Hirano, T., Hirata, R., Fujinuma, Y., Saigusa, N., Yamamoto, S., Hazarono, Y., Takada, M.,

\section{BGD}

6, 2863-2912, 2009

Seasonal variation in ecosystem

parameters derived

from FLUXNET data

M. Groenendijk et al.

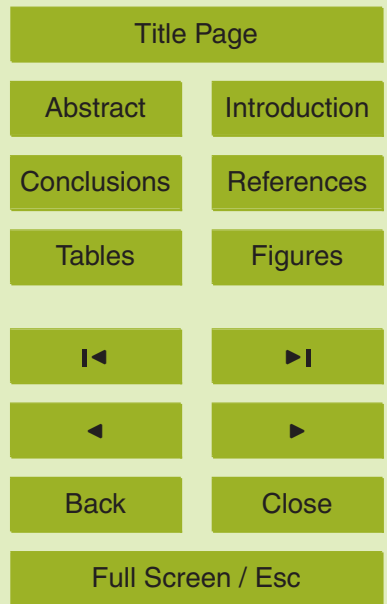

Printer-friendly Version

Interactive Discussion 
Inukai, $\mathrm{K}$., and Inoue, $\mathrm{G} .: \mathrm{CO}_{2}$ and water vapor exchange of a larch forest in northern Japan, Tellus, 55B, 244-257, doi:10.1034/j.1600-0889.2003.00063.x, 2003. 2903

Holdridge, L. R.: Determination of world plant formations from simple climatic data, Science, 105, 367-368, 1947. 2865

5 Hollinger, D. Y. and Richardson, A. D.: Uncertainty in eddy covariance measurements and its application to physiological models, Tree Physiol., 25, 873-885, 2005. 2872

Hollinger, D. Y., Aber, J., Dail, B., Davidson, E. A., Goltz, S. M., Hughes, H., Leclerc, M. Y., Lee, J. T., Richardson, A. D., Rodrigues, C., Scott, N. A., Achuatavarier, D., and Walsh, J.: Spatial and temporal variability in forest-atmosphere $\mathrm{CO}_{2}$ exchange, Glob. Change Biol., 10, $10 \quad$ 1689-1706, 2004. 2872, 2904

Humphreys, E. R., Black, T. A., Morgenstern, K., Cai, T., Drewitt, G. B., Nesic, Z., and Trofymow, J.: Carbon dioxide fluxes in coastal Douglas-fir stands at different stages of development after clearcut harvesting, the Fluxnet-Canada Research Network: Influence of Climate and Disturbance on Carbon Cycling in Forests and Peatlands, Agr. Forest Meteorol., 140, 6-22, doi:10.1016/j.agrformet.2006.03.018, 2006. 2902

Irvine, J. and Law, B. E.: Contrasting soil respiration in young and old-growth ponderosa pine forests, Glob. Change Biol., 8, 1183-1194, 2002. 2865

Jarvis, P. G., Massheder, J. M., Hale, S. E., Moncrieff, J. B., Rayment, M., and Scott, S. L.: Seasonal variation of carbon dioxide, water vapor, and energy exchanges of a boreal black spruce forest, J. Geophys. Res., 102, 28953-28966, 1997. 2902

Kleidon, A., Fraedrich, K., and Low, C.: Multiple steady-states in the terrestrial atmospherebiosphere system: a result of a discrete vegetation classification?, Biogeosciences, 4, 707714, 2007, http://www.biogeosciences.net/4/707/2007/. 2865

Knohl, A., Schulze, E.-D., Kolle, O., and Buchmann, N.: Large carbon uptake by an unmanaged 25 250-year-old deciduous forest in Central Germany, Agr. Forest. Meteorol., 118, 151-167, 2003. 2903

Kolari, P., Lappalainen, H. K., Hänninen, H., and Hari, P.: Relationship between temperature and the seasonal course of photosynthesis in Scots pine at northern timberline and in southern boreal zone, Tellus, 59B, 542-552, doi:10.1111/j.1600-0889.2007.00262.x, 2007. 2877

30 Köppen, W.: Klassifikation der Klimate nach Temperature, Niederschlag und Jahresverlauf, Peterm. Mit., 64, 193-203 und 243-248, 1918. 2865

Köppen, W.: Handbuch der Klimatologie, chap. Die Klimate der Erde, Gebrüder Bornträger, Berlin, 1936. 2865

Seasonal variation in ecosystem

parameters derived from FLUXNET data

M. Groenendijk et al.

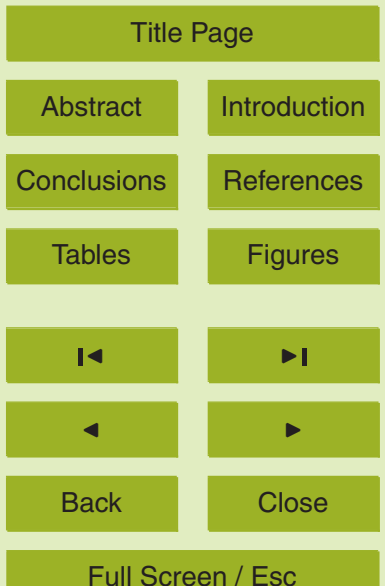

Full Screen / Esc

Printer-friendly Version

Interactive Discussion 
Kruijt, B., Elbers, J. A., von Randow, C., Arajo, A. C., Oliveira, P. J., Culf, A., Manzi, A. O., Nobre, A. D., Kabat, P., and Moors, E. J.: The Robustness of Eddy Correlation Fluxes for Amazon Rain Forest Conditions, Ecol. Appl., 14, S101-S113, http://www.jstor.org/stable/4493633, 2004. 2902

5 Lafleur, P. M., Roulet, N. T., and Admiral, S. W.: Annual cycle of $\mathrm{CO}_{2}$ exchange at a bog peatland, J. Geophys. Res., 106, 3071-3081, doi:10.1029/2000JD900588, 2001. 2902

Lagarias, J. C., Reeds, J. A., Wright, M. H., and Wright, P. E.: Convergence properties of the Nelder-Mead simplex method in low dimensions, SIAM J. Optimiz., 9, 122-147, 1998. 2871

Lasslop, G., Reichstein, M., Kattge, J., and Papale, D.: Influences of observation errors in eddy

10 flux data on inverse model parameter estimation, Biogeosciences, 5, 1311-1324, 2008, http://www.biogeosciences.net/5/1311/2008/. 2872, 2873

Law, B. E., Falge, E., Gu, L., Baldocchi, D. D., Bakwin, P., Berbigier, P., Davis, K. J., Dolman, A. J., Falk, M., Fuentes, J. D., Goldstein, A. H., Granier, A., Grelle, A., Hollinger, D., Janssens, I. A., Jarvis, P., Jensen, N. O., Katul, G., Mahli, Y., Matteucci, G., Meyers, T., Monson, R., Munger, W., Oechel, W., Olson, R., Paw U, K. T., Pilegaard, K., Thorgeirsson, H., Valentini, R., Verma, S., Vesala, T., Wilson, K., and Wofsy, S.: Environmental controls over carbon dioxide and water vapor exchange of terrestrial vegetation, Agr. Forest Meteorol., 113, 97120, doi:10.1016/S0168-1923(02)00104-1, 2002. 2865

Leuning, R.: A critical appraisal of a combined stomatal-photosynthesis model for $\mathrm{C}_{3}$ plants, Plant, Cell and Environment, 18, 339-355, 1995. 2878

Leuning, R., Cleugh, H. A., Zegelin, S. J., and Hughes, D.: Carbon and water fluxes over a temperate Eucalyptus forest and a tropical wet/dry savanna in Australia: measurements and comparison with MODIS remote sensing estimates, Agr. Forest. Meteorol., 129, 151-173, 2005. 2866, 2902

Lindroth, A., Grelle, A., and Morén, A.-S.: Long-term measurements of boreal forest carbon balance reveal large temperature sensitivity, Glob. Change Biol., 4, 443-450, doi:10.1046/j. 1365-2486.1998.00165.x, 1998. 2904

Lindroth, A., Lagergren, F., Aurela, M., Bjarnadottir, B., Christensen, T., Dellwik, E., Grelle, A., Ibrom, A., Johansson, T., Lankreijer, H., Launiainen, S., Laurila, T., Mölder, M., Nikinmaa, E., Pilegaard, K., Sigurdsson, B. D., and Vesala, T.: Leaf area index is the principal scaling parameter for both gross photosynthesis and ecosystem respiration of Northern deciduous and coniferous forests, Tellus, 60B, 129-142, doi:10.1111/j.1600-0889.2007.00330.x, 2008. 2866, 2877

Seasonal variation in ecosystem

parameters derived from FLUXNET data

M. Groenendijk et al.

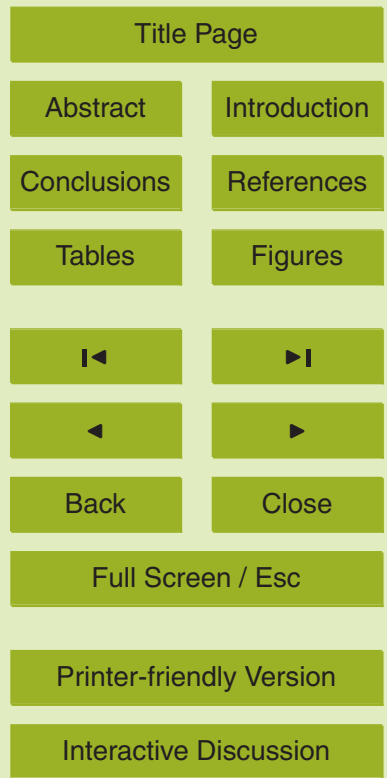

Interactive Discussion 
Liu, H., Randerson, J. T., Lindfors, J., and Chapin III, F. S.: Changes in the surface energy budget after fire in boreal ecosystems of interior Alaska: An annual perspective, J. Geophys. Res., 110, D13101, doi:10.1029/2004JD005158, 2005. 2904

Lloyd, J. and Taylor, A.: On the temperature dependence of soil respiration, Funct. Ecol., 8, 315-323, 1994. 2869

McCaughey, J., Pejam, M., Arain, M., and Cameron, D.: Carbon dioxide and energy fluxes from a boreal mixedwood forest ecosystem in Ontario, Canada, Agr. Forest Meteorol., 140, 79-96, doi:10.1016/j.agrformet.2006.08.010, 2006. 2902

Meyers, T. P.: A comparison of summertime water and $\mathrm{CO}_{2}$ fluxes over rangeland for 10 well watered and drought conditions, Agr. Forest Meteorol., 106, 205-214, doi:10.1016/ S0168-1923(00)00213-6, 2001. 2904

Misson, L., Tang, J., Xu, M., McKay, M., and Goldstein, A.: Influences of recovery from clearcut, climate variability, and thinning on the carbon balance of a young ponderosa pine plantation, Agr. Forest Meteorol., 130, 207-222, doi:10.1016/j.agrformet.2005.04.001, 2005. 2904

Moffat, A. M., Papale, D., Reichstein, M., Hollinger, D. Y., Richardson, A. D., Barr, A. G., Beckstein, C., Braswell, B. H., Churkina, G., Desai, A. R., Falge, E., Gove, J. H., Heimann, M., Hui, D., Jarvis, A. J., Kattge, J., Noormets, A., and Stauch, V. J.: Comprehensive comparison of gap-filling techniques for eddy covariance net carbon fluxes, Agr. Forest Meteorol., 147, 209-232, doi:10.1016/j.agrformet.2007.08.011, 2007. 2870

20 Monson, R. K., Turnipseed, A. A., Sparks, J. P., Harley, P. C., Scott-Denton, L. E., Sparks, K., and Huxman, T. E.: Carbon sequestration in a high-elevation, subalpine forest, Glob. Change Biol., 8, 459-478, doi:10.1046/j.1365-2486.2002.00480.x, 2002. 2904

Moureaux, C., Debacq, A., Bodson, B., Heinesch, B., and Aubinet, M.: Annual net ecosystem carbon exchange by a sugar beet crop, Agr. Forest Meteorol., 139, 25-39, doi:10.1016/j. agrformet.2006.05.009, 2006. 2902

Noormets, A., Chen, J., and Crow, T. R.: Age-Dependent Changes in Ecosystem Carbon Fluxes in Managed Forests in Northern Wisconsin, USA, Ecosystems, 10, 187-203, doi: 10.1007/s10021-007-9018-y, 2007. 2904

Papale, D. and Valentini, R.: A new asssesment of European forests carbon exchanges by eddy fluxes and artificial neural network spatialization, Glob. Change Biol., 9, 525-535, 2003. 2870

Papale, D., Reichstein, M., Aubinet, M., Canfora, E., Bernhofer, C., Kutsch, W., Longdoz, B., Rambal, S., Valentini, R., Vesala, T., and Yakir, D.: Towards a standardized processing of Net Ecosystem Exchange measured with eddy covariance technique: algorithms and uncertainty

Seasonal variation in ecosystem

parameters derived from FLUXNET data

M. Groenendijk et al.

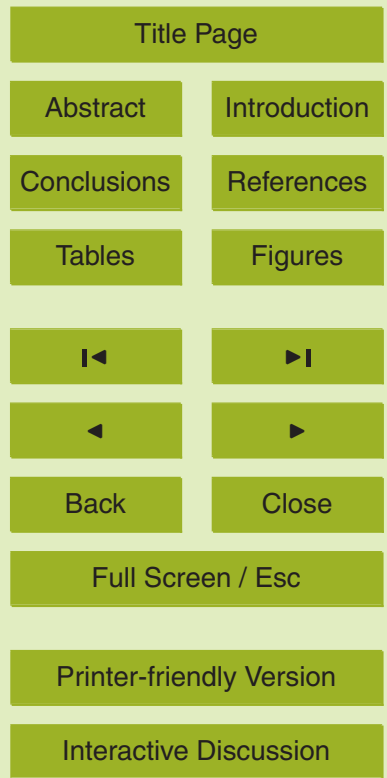


estimation, Biogeosciences, 3, 571-583, 2006, http://www.biogeosciences.net/3/571/2006/. 2870

Pilegaard, K., Mikkelsen, T. N., Beier, C., Jensen, N. O., Ambus, P., and Ro-Poulsen, H.: Field measurements of atmosphere-biosphere interactions in a Danish beech forest, Boreal. $5 \quad$ Environ. Res., 8, 315-333, 2003. 2903

Powell, T. L., Bracho, R., Li, J., Dore, S., Hinkle, C. R., and Drake, B. G.: Environmental controls over net ecosystem carbon exchange of scrub oak in central Florida, Agr. Forest. Meteorol., 141, 19-34, doi:10.1016/j.agrformet.2006.09.002, 2006. 2904

Rambal, S., Ourcival, J.-M., Joffre, R., Mouillot, F., Nouvellon, Y., Reichstein, M., and Rocheteau, A.: Drought controls over conductance and assimilation of a Mediterranean evergreen ecosystem: scaling from leaf to canopy, Glob. Change Biol., 9, 1813-1824, doi: 10.1111/j.1365-2486.2003.00687.x, 2003. 2903

Raupach, M. R., Rayner, P. J., Barnett, D. J., Defries, R. S., Heimann, M., Ojima, D. S., Quegan, S., and Schmullius, C. C.: Model-data synthesis in terrestrial carbon observations: methods, data requirements and data uncertainty specifications, Glob. Change Biol., 11, 378-397, 2005. 2872

Rebmann, C., Göckede, M., Foken, T., Aubinet, M., Aurela, M., Berbigier, P., Bernhofer, C., Buchmann, N., Carrara, A., Cescatti, A., Ceulemans, R., Clement, R., Elbers, J. A., Granier, A., Grünwald, T., Guyon, D., Havránková, K., Heinesch, B., Knohl, A., Laurila, T., Longdoz, B., Marcolla, B., Markkanen, T., Miglietta, F., Moncrieff, J., Montagnani, L., Moors, E., Nardino, M., Ourcival, J.-M., Rambal, S., Rannik, U., Rotenberg, E., Sedlak, P., Unterhuber, G., Vesala, T., and Yakir, D.: Quality analysis applied on eddy covariance measurements at complex forest sites using footprint modelling, Theor. Appl. Climatol., 80, 121-141, doi: 10.1007/s00704-004-0095-y, 2005. 2903

Reichstein, M., Tenhunen, J. D., Roupsard, O., Ourcival, J. M., Rambal, S., Miglietta, F., Peressotti, A., Pecchiari, M., Tirone, G., and Valentini, R.: Severe drought effects on ecosystem $\mathrm{CO}_{2}$ and $\mathrm{H}_{2} \mathrm{O}$ fluxes at three Mediterranean evergreen sites: revision of current hypotheses?, Glob. Change Biol., 8, 999-1017, 2002. 2903

Reichstein, M., Rey, A., Freibauer, A., Tenhunen, J., Valentini, R., Banza, J., Casals, P., Cheng, 30 Y., Grünzweig, J. M., Irvine, J., Joffre, R., Law, B. E., Loustau, D., Miglietta, F., Oechel, W., Ourcival, J.-M., Pereira, J. S., Peressotti, A., Ponti, F., Qi, Y., Rambal, S., Rayment, M., Romanya, J., Rossi, F., Tedeschi, V., Tirone, G., Xu, M., and Yakir, D.: Modeling temporal and large-scale spatial variability of soil respiration from soil water availability, temperature

\section{BGD}

6, 2863-2912, 2009

Seasonal variation in ecosystem

parameters derived from FLUXNET data

M. Groenendijk et al.

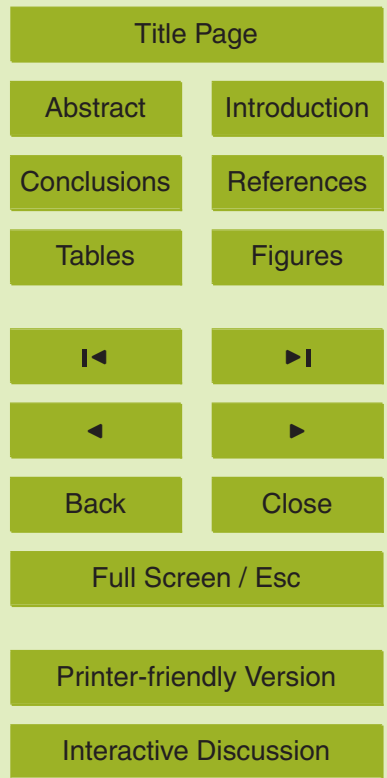


and vegetation productivity indices, Glob. Biochem. Cy., 17, 1104, 2003. 2903

Reichstein, M., Falge, E., Baldocchi, D., Papale, D., Aubinet, M., Berbignier, P., Bernhofer, C., Buchmann, N., Gilmanov, T., Granier, A., Grunwald, T., Havranovka, K., Ilvesniemi, H., Janous, D., Knohl, A., Laurila, T., Lohila, A., Loustau, D., Mattuecci, G., Meyers, T., Miglietta, F., Ourcival, J. M., Pumpanen, J., Rambal, S., Rotenberg, E., Sanz, M., Tenhunen, J., Seufert, G., Vaccari, F., Vesala, T., Yakir, D., and Valentini, R.: On the separation of net ecosystem exchange into assimilation and ecosystem respiration: review and improved algorithm, Glob. Change Biol., 11, 1424-1439, doi:10.1111/j.1365-2486.2005.001002.x, 2005. 2870, 2871, 2903

10 Reichstein, M., Papale, D., Valentini, R., Aubinet, M., Bernhofer, C., Knohl, A., Laurila, T., Lindroth, A., Moors, E., Pilegaard, K., and Seufert, G.: Determinants of terrestrial ecosystem carbon balance inferred from European eddy covariance flux sites, Geophys. Res. Lett., 34, L01402, doi:10.1029/2006GL027880, 2007. 2865, 2866

Restrepo, N. C. and Arain, M. A.: Energy and water exchanges from a temperate pine plantation forest, Hydrol. Process., 19, 27-49, doi:10.1002/hyp.5758, 2005. 2903

Rice, A. H., Pyle, E. H., Saleska, S. R., Hutyra, L., Palace, M., Keller, M., de Camargo, P. B., Portilho, K., Marques, D. F., and Wofsy, S. C.: Carbon balance and vegetation dynamics in an old-growth Amazonian forest, Ecol. Appl., 14, 55-71, doi:10.1890/02-6006, 2004. 2902

Richardson, A. D., Hollinger, D. Y., Burba, G. G., Davis, K. J., Flanagan, L. B., Katul, G. G., Munger, J. W., Ricciuto, D. M., Stoy, P. C., Suyker, A. E., Verma, S. B., and Wofsy, S. C.: A multi-site analysis of random error in tower-based measurements of carbon and energy fluxes, Agr. Forest Meteorol., 136, 1-18, 2006. 2872, 2873

Richardson, A. D., Mahecha, M. D., Falge, E., Kattge, J., A. M. Moffat, Papale, D., Reichstein, M., Stauch, V. J., Braswell, B. H., Churkina, G., Kruijt, B., and Hollinger, D. Y.: Statistical properties of random $\mathrm{CO}_{2}$ flux measurment uncertainty inferred from model residuals, Agr. Forest Meteorol., 148, 38-50, 2008. 2872

Rodeghiero, M. and Cescatti, A.: Main determinants of forest soil respiration along an elevation/temperature gradient in the Italian Alps, Glob. Change Biol., 11, 1024-1041, 2005. 2903

so Rossi, F., Facini, O., Georgiadis, T., Spano, D., and Duce, P.: Water, Heat and Energy Fluxes over a Mediterranean Vegetation Surface, 23rd Conference on Agr. Forest. Meteorol., Albuquerque, New Mexico, USA, 264-267, 1998. 2903

Roupsard, O., Bonnefond, J.-M., Irvine, M., Berbigier, P., Nouvellon, Y., Dauzat, J., Taga, S.,

\section{BGD}

6, 2863-2912, 2009

Seasonal variation in ecosystem

parameters derived

from FLUXNET data

M. Groenendijk et al.

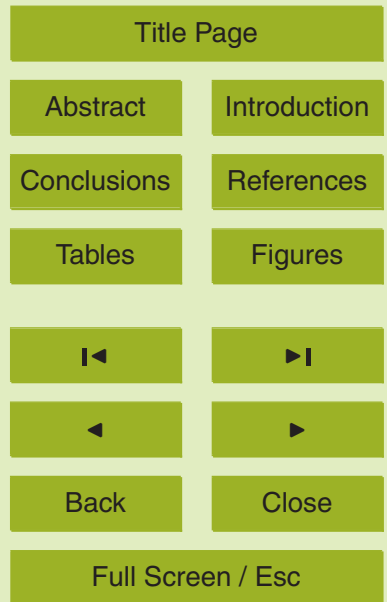

Printer-friendly Version

Interactive Discussion 
Hamel, O., Jourdan, C., Saint-André, L., Mialet-Serra, I., Labouisse, J.-P., Epron, D., Joffre, R., Braconnier, S., Rouzière, A., Navarro, M., and Bouillet, J.-P.: Partitioning energy and evapo-transpiration above and below a tropical palm canopy, Agr. Forest Meteorol., 139, 252-268, doi:10.1016/j.agrformet.2006.07.006, 2006. 2904

5 Sanz, M. J., Carrara, A., and Gimeno, C.: Effects of a dry and warm summer conditions on $\mathrm{CO}_{2}$ and energy fluxes from three Meditteranean ecosystems, Geophys. Res. Abstr., 6, 3239, 2004. 2903

Schmid, H. P., Grimmond, C. S. B., Cropley, F., Offerle, B., and Su, H.-B.: Measurements of $\mathrm{CO}_{2}$ and energy fluxes over a mixed hardwood forest in the mid-western United States, Agr.

10 Forest Meteorol., 103, 357-374, doi:10.1016/S0168-1923(00)00140-4, 2000. 2904

Schymanski, S. J., Roderick, M. L., Sivapalan, M., Hutley, L. B., and Beringer, J.: A canopyscale test of the optimal water-use hypothesis, Plant, Cell and Environment, 31, 97-111, doi:10.1111/j.1365-3040.2007.01740.x, 2007. 2878

Scott, R. L., Huxman, T. E., Williams, D. G., and Goodrich, D. C.: Ecohydrological impacts of 15 woody-plant encroachment: seasonal patterns of water and carbon dioxide exchange within a semiarid riparian environment, Glob. Change Biol., 12, 311-324, doi:10.1111/j.1365-2486. 2005.01093.x, 2006. 2904

Sellers, P. J., Mintz, Y., Sud, Y., and Dalcher, A.: A simple biosphere model (SiB) for use within General Circulation Models, J. Atmos. Sci., 43, 505-531, doi:10.1175/1520-0469(1986) 043/0505:ASBMFU)2.0.CO;2, 1986. 2865

Sigurdsson, B. D., Thorgeirsson, H., and Linder, S.: Growth and dry-matter partitioning of young Populus trichocarpa in response to carbon dioxide concentration and mineral nutrient availability, Tree Physiol., 21, 941-950, 2001. 2903

Sluis, W. J.: Patterns of Species Richness and Composition in Re-Created Grassland, Restor. Ecol., 10, 677-684, doi:10.1046/j.1526-100X.2002.01048.x, 2002. 2904

Stoy, P. C., Katul, G. G., Siqueira, M. B. S., Juang, J. Y., Novick, K. A., Uebelherr, J. M., and Oren, R.: An evaluation of models for partitioning eddy covariance-measured net ecosystem exchange into photosynthesis and respiration, Agr. Forest Meteorol., 141, 2-18, 2006. 2869

Subke, J.-A. and Tenhunen, J. D.: Direct measurements of $\mathrm{CO}_{2}$ flux below a spruce forest canopy, Agr. Forest Meteorol., 126, 157-168, doi:10.1016/j.agrformet.2004.06.007, 2004. 2903

Suni, T., Rinne, J., Reissell, A., Altimir, N., Keronen, P., Rannik, Ü., Maso, M. D., Kulmala, M., and Vesala, T.: Long-term measurements of surface fluxes above a Scots pine forest in

Seasonal variation in ecosystem

parameters derived

from FLUXNET data

M. Groenendijk et al.

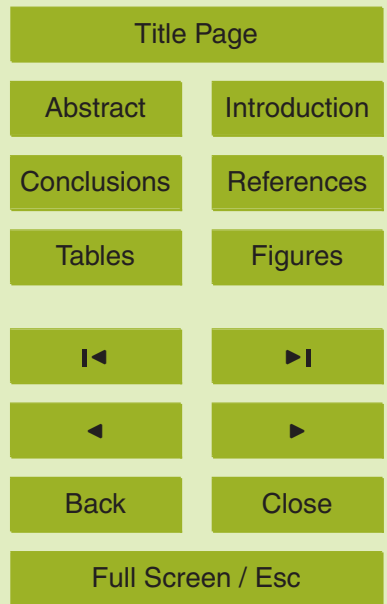

Printer-friendly Version

Interactive Discussion 
Hyytiälä, southern Finland, 1996-2001, Boreal Environ. Res., 8, 287-301, 2003. 2903

Syed, K. H., Flanagan, L. B., Carlson, P. J., Glenn, A. J., and Gaalen, K. E. V.: Environmental control of net ecosystem $\mathrm{CO}_{2}$ exchange in a treed, moderately rich fen in northern Alberta, Agr. Forest Meteorol., 140, 97-114, doi:10.1016/j.agrformet.2006.03.022, 2006. 2903

5 Tchebakova, N. M., Kolle, O., Zolotoukhine, D., Arneth, A., Styles, J. M., Vygodskaya, N. N., Schulze, E.-D., Shibistova, O., and LLoyd, J.: Inter-annual and seasonal variations of energy and water vapour fluxes above a Pinus sylvestris forest in the Siberian middle taiga, Tellus, 54B, 537-551, doi:10.1034/j.1600-0889.2002.01337.x, 2002. 2904

Tedeschi, V., Rey, A., Manca, G., Valentini, R., Jarvis, P. G., and Borghetti, M.: Soil respiration in a Mediterranean oak forest at different developmental stages after coppicing, Glob. Change Biol., 12, 110-121, doi:10.1111/j.1365-2486.2005.01081.x, 2005. 2903

Thum, T., Aalto, T., Laurila, T., Aurela, M., Lindroth, A., and Vesala, T.: Asessing seasonality of biochemical $\mathrm{CO}_{2}$ exhange model parameters from micrometeorological flux observations at boreal coniferous forest, Biogeosciences, 5, 1625-1639, 2008,

15 http://www.biogeosciences.net/5/1625/2008/. 2879

Valentini, R., Angelis, P. D., Matteuci, G., Monaco, R., Dore, S., and Scarascia Mucnozza, G. E.: Seasonal net carbon dioxide exchange of a beech forest with the atmosphere, Glob. Change Biol., 2, 199-207, doi:10.1111/j.1365-2486.1996.tb00072.x, 1996. 2903

Valentini, R., Matteucci, G., Dolman, A. J., Schulze, E.-D., Rebmann, C., Moors, E. J., Granier, A., Gross, P., Jensen, N. O., Pilegaard, K., Lindroth, A., Grelle, A., Bernhofer, C., Grünwald, T., Aubinet, M., Ceulemans, R., Kowalski, A. S., Vesala, T., Rannik, Ü., Berbigier, P., Loustau, D., Gudmundsson, J., Thorgeirsson, H., Ibrom, A., Morgenstern, K., Clement, R., Moncrieff, J., Montagnani, L., Minerbi, S., and Jarvis, P. G.: Respiration as the main determinant of carbon balance in European forests, Nature, 404, 861-865, 2000. 2904

van der Tol, C., Dolman, A. J., Waterloo, M. J., and Raspor, K.: Topography induced spatial variations in diurnal cycles of assimilation and latent heat of Mediterranean forest, Biogeosciences, 4, 137-154, 2007, http://www.biogeosciences.net/4/137/2007/. 2866, 2878

van Dijk, A. J. and Dolman, A. J.: Estimates of $\mathrm{CO}_{2}$ uptake and release among European forests based on eddy covariance data, Glob. Change Biol., 10, 1445-1459, 2004. 2869

30 van Dijk, A. J., Dolman, A. J., and Schulze, E. D.: Radiation, temperature and leaf area explain most variation in net ecosystem exchange among European forests, Global Biogeochem. Cy., 19, GB2029, doi:10.1029/2004GB002417, 2005. 2866

Veenendaal, E. M., Kolle, O., and Lloyd, J.: Seasonal variation in energy fluxes and carbon diox-
BGD

6, 2863-2912, 2009

Seasonal variation in ecosystem

parameters derived

from FLUXNET data

M. Groenendijk et al.

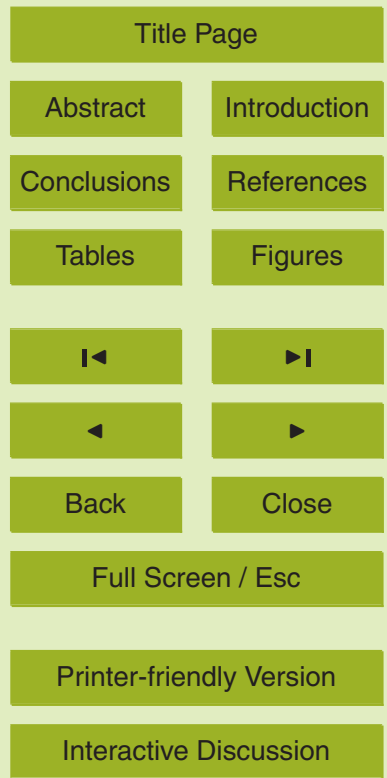


ide exchange for a broad-leaved semi-arid savanna (Mopane woodland) in Southern Africa, Glob. Change Biol., 10, 318-328, doi:10.1111/j.1365-2486.2003.00699.x, 2004. 2902

Verma, S. B., Dobermann, A., Cassman, K. G., Walters, D. T., Knops, J. M., Arkebauer, T. J., Suyker, A. E., Burba, G. G., Amos, B., Yang, H., Ginting, D., Hubbard, K. G., Gitelson, A. A., and Walter-Shea, E. A.: Annual carbon dioxide exchange in irrigated and rainfed maizebased agroecosystems, Agr. Forest. Meteorol., 131, 77-96, doi:10.1016/j.agrformet.2005. 05.003, 2005. 2904

von Caemmerer, S. and Farquhar, G. D.: Some relationships between the biochemistry of photosynthesis and the gas exchange of leaves, Planta, 153, 376-387, 1981. 2881

Wang, Q., Tenhunen, J., Falge, E., Bernhofer, C., Granier, A., and Vesala, T.: Simulation and scaling of temporal variations in gross primary production for coniferous and deciduous temperate forests, Glob. Change Biol., 10, 37-51, 2003. 2878

Wang, Y. P., Baldocchi, D., Leuning, R., Falge, E., and Vesala, T.: Estimating parameters in a land-surface model by applying nonlinear inversion to eddy covariance flux measurements from eight FLUXNET sites, Glob. Change Biol., 12, 1-19, 2007. 2878

Wilson, K. B., Baldocchi, D. D., and Hanson, P. J.: Leaf age affects the sesonal pattern of photosynthetic capacity and net ecosystem exchange of carbon in a deciduous forest, Plant, Cell and Environment, 24, 571-583, 2001. 2877, 2878

Wofsy, S. C., Goulden, M. L., Munger, J. W., Fan, S.-M., Bakwin, P. S., Daube, B. C., Bassow, S. L., and Bazzaz, F. A.: Net Exchange of $\mathrm{CO}_{2}$ in a Mid-Latitude Forest, Science, 260, 1314-1317, doi:10.1126/science.260.5112.1314, 1993. 2904

Wohlfahrt, G., Bahn, M., Haslwanter, A., Newesely, C., and Cernusca, A.: Estimation of daytime ecosystem respiration to determine gross primary production of a mountain meadow, Agr. Forest. Meteorol., 130, 13-25, doi:10.1016/j.agrformet.2005.02.001, 2005. 2902

Woodward, F. I., Lomas, M. R., and Betts, R. A.: Vegetation-climate feedbacks in a greenhouse world, Philos. T. Roy. Soc. B, 353, 29-39, doi:10.1098/rstb.1998.0188, 1998. 2865

Xu, L. and Baldocchi, D. B.: Seasonal variation in carbon dioxide exchange over a Mediterranean annual grassland in California, Agr. Forest Meteorol., 1232, 79-96, 2004. 2904

Yamamoto, S., Murayama, S., Saigusa, N., and Kondo, H.: Seasonal and inter-annual variation 30 of $\mathrm{CO}_{2}$ flux between a temperate forest and the atmosphere in Japan, Tellus, 51B, 402-413, doi:10.1034/j.1600-0889.1999.00020.x, 1999. 2903

BGD

6, 2863-2912, 2009

Seasonal variation in ecosystem

parameters derived

from FLUXNET data

M. Groenendijk et al.

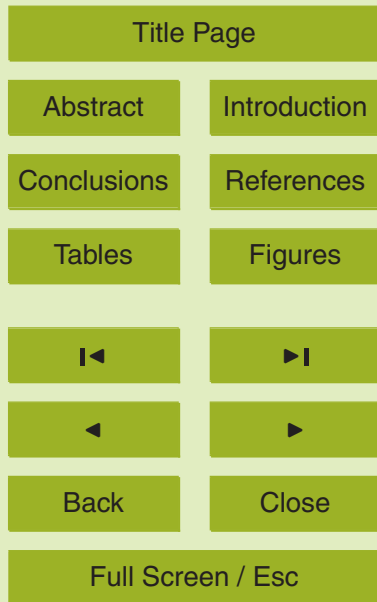

Printer-friendly Version

Interactive Discussion 
BGD

6, 2863-2912, 2009

Seasonal variation in ecosystem

Table 1. Number of FLUXNET sites used in this study in plant functional types as classes of vegetation and climate.

\begin{tabular}{|c|c|c|c|c|c|c|c|}
\hline & Boreal & Dry & $\begin{array}{r}\text { Subtropical } \\
\text { Mediterranean }\end{array}$ & Temperate & $\begin{array}{l}\text { Temperate } \\
\text { Continental }\end{array}$ & Tropical & Total \\
\hline Cropland & & & 2 & 6 & 6 & & 14 \\
\hline Closed shrubland & & & 3 & & & & 3 \\
\hline Deciduous broadleaf forest & 1 & & 5 & 3 & 4 & & 13 \\
\hline Evergreen broadleaf forest & & 1 & 4 & 1 & & 4 & 10 \\
\hline Evergreen needleleaf forest & 17 & 1 & 5 & 10 & 5 & & 39 \\
\hline Grassland & 2 & 1 & 6 & 10 & 5 & & 24 \\
\hline Mixed Forest & 2 & & & 1 & 4 & & 7 \\
\hline Open shrubland & 1 & & 1 & & 1 & & 3 \\
\hline Savanna & & & 1 & & & & 1 \\
\hline Wetland & 1 & & & & & & 1 \\
\hline Woody Savanna & & 2 & 4 & & & 1 & 7 \\
\hline Total & 24 & 5 & 31 & 31 & 25 & 5 & 121 \\
\hline
\end{tabular}

from FLUXNET data

M. Groenendijk et al.

Full Screen / Esc

Printer-friendly Version

Interactive Discussion

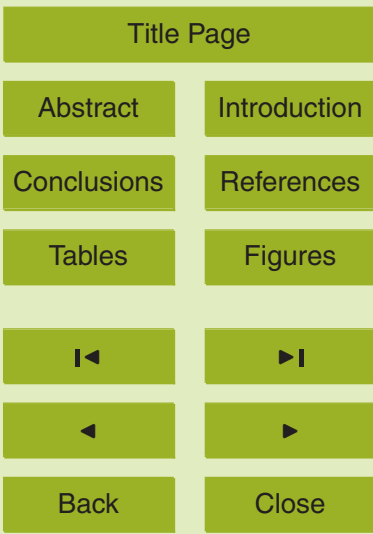


Table 2. Parameters used in this study in the photosynthesis and transpiration module of the 5PM model.

\begin{tabular}{lll}
\hline Parameter & Description & Value \\
\hline$V_{c m}$ & Carboxylation capacity $\left(\mu \mathrm{mol} \mathrm{m}^{-2} \mathrm{~s}^{-1}\right)$ & variable \\
$J_{m}$ & Electron transport rate, $\left(\mu \mathrm{mol} \mathrm{m}^{-2} \mathrm{~s}^{-1}\right)$ & variable \\
$\alpha$ & Quantum yield (mol mol $\left.{ }^{-1}\right)$ & variable \\
$\lambda$ & Intrinsic water use efficiency $\left(\mathrm{mol} \mathrm{mol}^{-1}\right)$ & variable \\
$O$ & $\mathrm{O}_{2}$ concentration (mbar) & 209 \\
$T_{\text {ref }}$ & Reference temperature $(\mathrm{K})$ & 298 \\
$K_{c}$ & Kinetic coefficient for $\mathrm{CO}_{2}$ at $T_{\text {ref }}(\mu \mathrm{bar})$ & 460 \\
$K_{o}$ & Kinetic coefficient for $\mathrm{O}_{2}$ at $T_{\text {ref }}(\mathrm{mbar})$ & 330 \\
$E_{k c}$ & Activation energy for $\mathrm{CO}_{2}\left(\mathrm{~J} \mathrm{~mol}^{-1}\right)$ & 59356 \\
$E_{J m}$ & Activation energy for $\mathrm{J}_{m}\left(\mathrm{~J} \mathrm{~mol}^{-1}\right)$ & 45000 \\
$J_{m} / V_{c m}$ & Ratio & 2.5 \\
$V_{o m} / V_{c m}$ & Ratio & 0.21 \\
\hline
\end{tabular}

Seasonal variation in ecosystem

parameters derived from FLUXNET data

M. Groenendijk et al.

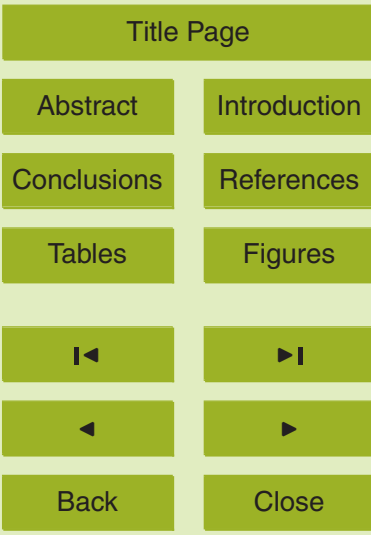

Full Screen / Esc

Printer-friendly Version

Interactive Discussion 
BGD

6, 2863-2912, 2009

Seasonal variation in ecosystem

parameters derived from FLUXNET data

Table 3. Details of principal component analysis with explained variation (\%) and loadings (-) of model parameters for classes of vegetation.

\begin{tabular}{lrrrrrrr}
\hline & $\begin{array}{r}\text { Number } \\
\text { of sites }\end{array}$ & $\begin{array}{r}\text { Explained } \\
\text { variation }\end{array}$ & $\begin{array}{r}\text { Loadings } \\
R_{\text {ref }}\end{array}$ & $E_{0}$ & $J_{m}$ & $\alpha$ & $1 / \lambda$ \\
\hline All site & 121 & 36.78 & 0.38 & 0.34 & 0.49 & 0.56 & 0.44 \\
Cropland & 14 & 38.20 & 0.27 & 0.06 & 0.58 & 0.58 & 0.50 \\
Closed shrubland & 3 & 45.03 & 0.57 & -0.42 & 0.49 & 0.44 & 0.25 \\
Deciduous broadleaf forest & 13 & 44.71 & 0.22 & 0.27 & 0.55 & 0.53 & 0.54 \\
Evergreen broadleaf forest & 10 & 43.19 & -0.41 & 0.63 & 0.40 & 0.33 & 0.41 \\
Evergreen needleleaf forest & 39 & 41.14 & 0.43 & 0.39 & 0.49 & 0.51 & 0.40 \\
Grassland & 24 & 40.59 & 0.59 & 0.12 & 0.56 & 0.54 & 0.18 \\
Mixed Forest & 7 & 48.14 & 0.51 & 0.17 & 0.48 & 0.52 & 0.45 \\
Open shrubland & 3 & 44.49 & 0.42 & 0.35 & 0.54 & 0.26 & 0.59 \\
Woody Savanna & 7 & 33.33 & 0.17 & 0.50 & 0.58 & 0.59 & 0.20 \\
\hline
\end{tabular}

M. Groenendijk et al.

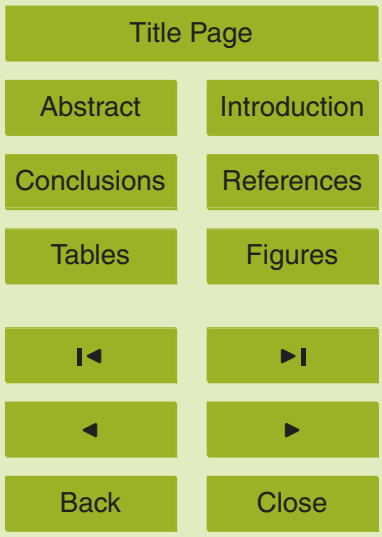

Full Screen / Esc

Printer-friendly Version 
BGD

6, 2863-2912, 2009

Seasonal variation in ecosystem

parameters derived from FLUXNET data

of photosynthesis and transpiration model parameters for classes of vegetation.

\begin{tabular}{lrrrrr}
\hline & $\begin{array}{r}\text { Number } \\
\text { of sites }\end{array}$ & $\begin{array}{r}\text { Explained } \\
\text { variation }\end{array}$ & $\begin{array}{r}\text { Loadings } \\
J_{m}\end{array}$ & $\alpha$ & $1 / \lambda$ \\
\hline All site & 121 & 50.45 & 0.58 & 0.58 & 0.57 \\
Cropland & 14 & 60.99 & 0.59 & 0.60 & 0.54 \\
Closed shrubland & 3 & 50.30 & 0.66 & 0.62 & 0.43 \\
Deciduous broadleaf forest & 13 & 68.47 & 0.60 & 0.55 & 0.59 \\
Evergreen broadleaf forest & 10 & 45.81 & 0.62 & 0.58 & 0.53 \\
Evergreen needleleaf forest & 39 & 52.15 & 0.59 & 0.58 & 0.55 \\
Grassland & 24 & 47.58 & 0.66 & 0.66 & 0.37 \\
Mixed Forest & 7 & 60.46 & 0.58 & 0.58 & 0.57 \\
Open shrubland & 3 & 56.73 & 0.64 & 0.39 & 0.66 \\
Woody Savanna & 7 & 45.05 & 0.68 & 0.64 & 0.36 \\
\hline
\end{tabular}

M. Groenendijk et al.

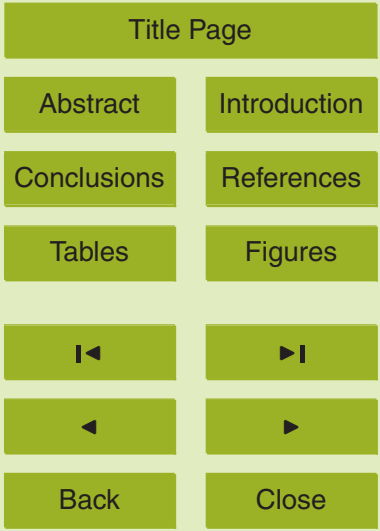

Full Screen / Esc

Printer-friendly Version

Interactive Discussion 
Table 5. Stepwise multiple regression of weekly model parameters with weekly average air temperature $\left(T_{a}\right)$, global radiation $\left(R_{g}\right)$, vapour pressure deficit $(V P D)$ and soil water content $(S W C)$.

\begin{tabular}{|c|c|c|c|c|c|c|c|}
\hline & Parameter & Intercept & $T_{a}$ & $R_{g}$ & $V P D$ & $S W C$ & $r^{2}$ \\
\hline All site & $\begin{array}{r}R_{\text {ref }} \\
E_{0} \\
J_{m} \\
\alpha \\
1 / \lambda\end{array}$ & $\begin{array}{r}3.07 \\
169.76 \\
-5.24 \\
0.33 \\
0.38\end{array}$ & $\begin{array}{l}0.02 \\
4.01 \\
8.15 \\
0.01 \\
0.02\end{array}$ & 0.01 & $\begin{array}{l}-0.21 \\
-0.02\end{array}$ & $\begin{array}{r}-0.005 \\
1.12 \\
-0.002 \\
-0.003\end{array}$ & $\begin{array}{l}0.09 \\
0.01 \\
0.07 \\
0.11 \\
0.02\end{array}$ \\
\hline Deciduous broadleaf forest & $\begin{array}{r}R_{\text {ref }} \\
E_{0} \\
J_{m} \\
\alpha \\
1 / \lambda\end{array}$ & $\begin{array}{r}3.63 \\
-15.79 \\
0.30 \\
0.05\end{array}$ & $\begin{array}{r}11.71 \\
0.02 \\
0.05\end{array}$ & 0.01 & $\begin{array}{l}-0.19 \\
-0.03\end{array}$ & -0.03 & $\begin{array}{l}0.07 \\
0.45 \\
0.28 \\
0.22\end{array}$ \\
\hline Evergreen broadleaf forest & $\begin{array}{r}R_{\text {ref }} \\
E_{0} \\
J_{m} \\
\alpha \\
1 / \lambda\end{array}$ & $\begin{array}{r}1.96 \\
254.96 \\
118.80 \\
0.32\end{array}$ & -0.01 & & & $\begin{array}{l}0.03 \\
4.05 \\
4.31 \\
0.01\end{array}$ & $\begin{array}{l}0.06 \\
0.03 \\
0.08 \\
0.32\end{array}$ \\
\hline Evergreen needleleaf forest & $\begin{array}{r}R_{\text {ref }} \\
E_{0} \\
J_{m} \\
\alpha \\
1 / \lambda\end{array}$ & $\begin{array}{r}3.91 \\
209.69 \\
73.85 \\
0.39 \\
0.42\end{array}$ & $\begin{array}{l}0.06 \\
3.26 \\
4.22 \\
0.01 \\
0.03\end{array}$ & & $\begin{array}{l}-0.18 \\
-0.03\end{array}$ & $\begin{array}{r}-0.01 \\
-1.27 \\
-0.73 \\
-0.002 \\
-0.01\end{array}$ & $\begin{array}{l}0.03 \\
0.01 \\
0.04 \\
0.13 \\
0.01\end{array}$ \\
\hline Grassland & $\begin{array}{r}R_{\text {ref }} \\
E_{0} \\
J_{m} \\
\alpha \\
1 / \lambda\end{array}$ & $\begin{array}{r}1.26 \\
146.62 \\
-76.14 \\
0.20 \\
0.63\end{array}$ & $\begin{array}{r}0.10 \\
4.66 \\
12.53 \\
0.01\end{array}$ & $\begin{array}{l}0.01 \\
0.45\end{array}$ & $\begin{array}{r}-0.31 \\
-5.12 \\
-16.10 \\
-0.02\end{array}$ & $\begin{array}{r}0.02 \\
\\
1.80 \\
0.001 \\
-0.01\end{array}$ & $\begin{array}{r}0.25 \\
0.01 \\
0.23 \\
0.15 \\
0.004\end{array}$ \\
\hline
\end{tabular}

BGD

6, 2863-2912, 2009

Seasonal variation in ecosystem parameters derived from FLUXNET data

\section{Groenendijk et al.}

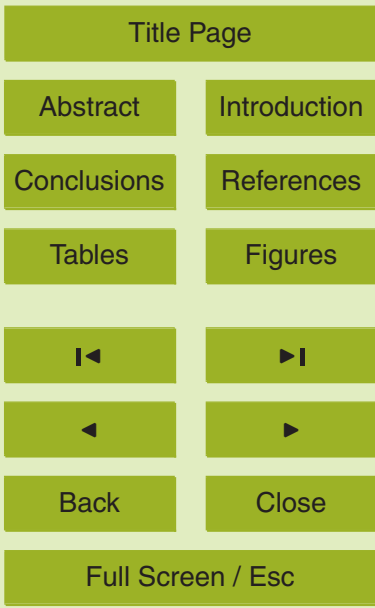

Printer-friendly Version

Interactive Discussion 
Table B1. Site characteristics of the FLUXNET sites used in this study. The site name codes are composed by the country (first two letters) and site name (last three letters). Vegetation types are closed shrubland (CSH), cropland (CRO), deciduous broadleaf forest (DBF), evergreen broadleaf forest (EBF), evergreen needleleaf forest (ENF), grassland (GRA), mixed forest (MFO), open shrubland (OSH), savanna (SAV), wetland (WET) and woody savanna (WSA). Climate regions are arctic $(\mathrm{AR})$, boreal $(\mathrm{BO})$, dry (DR), subtropical-Mediterranean (SM), temperate (TE), temperate-continental (TC) and tropical (TR). The friction velocity thresholds $\left(u_{*}, \mathrm{~m} \mathrm{~s}^{-1}\right)$ are used to select turbulent nighttime data. For each site the average ( \pm standard deviation) of each parameter is given of all weekly values derived for a site. $R_{\text {ref }}$ and $J_{m}$ are presented in $\mu \mathrm{mol} \mathrm{m}{ }^{-2} \mathrm{~s}^{-1}, E_{0}$ in $\mathrm{K}, \alpha$ in mol mol${ }^{-1}$ and $1 / \lambda$ in $\mu \mathrm{mol} \mathrm{mol}^{-1}$. References are given describing the sites, when no reference was available the site researcher is named.

\begin{tabular}{|c|c|c|c|c|c|c|c|c|c|}
\hline Site & Vegetation & Climate & $u_{*}$ & $R_{\text {ref }}$ & $E_{0}$ & $J_{m}$ & $\alpha$ & $1 / \lambda$ & Reference or PI \\
\hline AU-How & WSA & TR & 0.40 & $1.39 \pm 1.39$ & $447.2 \pm 464.6$ & $221.2 \pm 184.4$ & $0.26 \pm 0.15$ & $0.47 \pm 0.54$ & Beringer et al. (2007) \\
\hline AU-Tum & EBF & TE & 0.32 & $5.30 \pm 1.14$ & $41.8 \pm 18.0$ & $216.3 \pm 198.1$ & $0.25 \pm 0.11$ & $0.32 \pm 0.59$ & Leuning et al. (2005) \\
\hline BR-Ban & EBF & TR & 0.13 & $1.23 \pm 1.48$ & $608.3 \pm 420.8$ & $408.3 \pm 181.0$ & $0.38 \pm 0.13$ & $1.19 \pm 1.31$ & Humberto da Rocha \\
\hline BR-Ma2 & EBF & TR & 0.14 & $3.58 \pm 2.70$ & $454.8 \pm 432.5$ & $516.3 \pm 259.4$ & $0.58 \pm 0.10$ & $1.27 \pm 0.42$ & Kruijt et al. (2004) \\
\hline BR-Sa1 & EBF & TR & 0.30 & $2.93 \pm 2.71$ & $616.6 \pm 532.7$ & $422.6 \pm 286.6$ & $0.57 \pm 0.17$ & $0.70 \pm 0.37$ & Rice et al. (2004) \\
\hline BW-Ma1 & WSA & DR & 0.14 & $1.08 \pm 0.89$ & $117.0 \pm 82.2$ & $42.3 \pm 40.0$ & $0.12 \pm 0.12$ & $0.38 \pm 0.26$ & Veenendaal et al. (2004) \\
\hline CA-Ca3 & ENF & TE & 0.16 & $3.89 \pm 1.30$ & $231.8 \pm 241.5$ & $113.2 \pm 141.6$ & $0.34 \pm 0.14$ & $0.58 \pm 0.93$ & Humphreys et al. (2006) \\
\hline CA-Gro & MFO & TC & 0.31 & $3.18 \pm 1.51$ & $101.7 \pm 57.5$ & $135.6 \pm 188.1$ & $0.27 \pm 0.17$ & $0.24 \pm 0.16$ & McCaughey et al. (2006) \\
\hline CA-Let & GRA & TC & 0.27 & $1.64 \pm 0.95$ & $141.8 \pm 129.5$ & $91.2 \pm 86.3$ & $0.14 \pm 0.10$ & $0.32 \pm 0.30$ & Flanagan et al. (2002) \\
\hline CA-Man & ENF & BO & 0.39 & $2.64 \pm 1.13$ & $170.2 \pm 108.8$ & $63.9 \pm 26.3$ & $0.33 \pm 0.14$ & $0.35 \pm 0.33$ & Dunn et al. (2007) \\
\hline CA-Mer & $\mathrm{OSH}$ & TC & 0.04 & $1.68 \pm 0.55$ & $114.9 \pm 86.0$ & $57.5 \pm 27.2$ & $0.21 \pm 0.09$ & $0.10 \pm 0.06$ & Lafleur et al. (2001) \\
\hline CA-NS1 & ENF & BO & 0.38 & $2.51 \pm 2.93$ & $176.1 \pm 128.8$ & $72.4 \pm 36.1$ & $0.25 \pm 0.11$ & $0.59 \pm 1.04$ & Goulden et al. (2006) \\
\hline CA-NS2 & ENF & BO & 0.44 & $1.64 \pm 0.52$ & $207.0 \pm 148.4$ & $73.4 \pm 42.5$ & $0.23 \pm 0.10$ & $0.54 \pm 0.36$ & Goulden et al. (2006) \\
\hline CA-Obs & ENF & BO & 0.24 & $2.77 \pm 1.18$ & $113.9 \pm 69.8$ & $63.7 \pm 29.4$ & $0.24 \pm 0.11$ & $0.33 \pm 0.15$ & Jarvis et al. (1997) \\
\hline CA-Ojp & ENF & BO & 0.25 & $2.20 \pm 0.98$ & $133.8 \pm 84.0$ & $50.7 \pm 25.3$ & $0.22 \pm 0.11$ & $0.36 \pm 0.21$ & Chen et al. (2006) \\
\hline CA-Qcu & ENF & $\mathrm{BO}$ & 0.31 & $2.49 \pm 0.93$ & $172.8 \pm 131.6$ & $43.0 \pm 15.5$ & $0.18 \pm 0.08$ & $0.08 \pm 0.06$ & Giasson et al. (2006) \\
\hline CA-SF1 & ENF & $\mathrm{BO}$ & 0.26 & $4.10 \pm 2.00$ & $181.6 \pm 103.2$ & $101.4 \pm 42.3$ & $0.31 \pm 0.13$ & $0.31 \pm 0.17$ & Amiro et al. (2006) \\
\hline CA-SF2 & ENF & BO & 0.20 & $3.57 \pm 2.23$ & $216.6 \pm 155.9$ & $125.2 \pm 85.6$ & $0.34 \pm 0.18$ & $0.60 \pm 0.41$ & Amiro et al. (2006) \\
\hline CA-SJ1 & ENF & BO & 0.31 & $1.09 \pm 0.41$ & $244.9 \pm 155.5$ & $38.0 \pm 20.3$ & $0.10 \pm 0.04$ & $0.15 \pm 0.14$ & Chen et al. (2006) \\
\hline
\end{tabular}

\section{Seasonal variation in ecosystem \\ parameters derived from FLUXNET data}

\section{Groenendijk et al.}

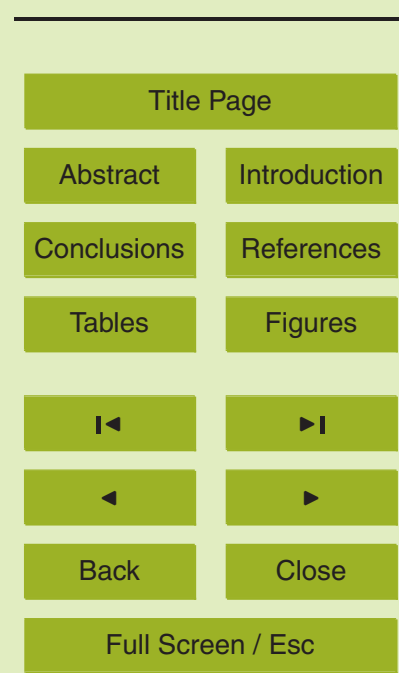

Printer-friendly Version

Interactive Discussion 


\begin{tabular}{|c|c|c|c|c|c|c|c|c|c|}
\hline Site & Vegetation & Climate & $u_{*}$ & $R_{\text {ref }}$ & $E_{0}$ & $J_{m}$ & $\alpha$ & $1 / \lambda$ & Reference or PI \\
\hline CA-TP4 & ENF & TC & 0.46 & $2.85 \pm 1.39$ & $248.7 \pm 325.8$ & $96.1 \pm 64.1$ & $0.34 \pm 0.16$ & $1.52 \pm 6.29$ & Restrepo and Arain (2005) \\
\hline CA-WP1 & MFO & BO & 0.09 & $1.99 \pm 0.96$ & $135.3 \pm 139.4$ & $87.4 \pm 60.6$ & $0.15 \pm 0.09$ & $0.21 \pm 0.15$ & Syed et al. (2006) \\
\hline $\mathrm{CH}-\mathrm{Oe} 1$ & GRA & TE & 0.09 & $4.52 \pm 1.71$ & $250.8 \pm 214.0$ & $188.3 \pm 104.8$ & $0.41 \pm 0.15$ & $0.41 \pm 0.34$ & Gilmanov et al. (2007) \\
\hline CN-Du2 & GRA & TC & 0.11 & $1.57 \pm 1.14$ & $174.6 \pm 91.8$ & $51.6 \pm 32.9$ & $0.11 \pm 0.07$ & $0.09 \pm 0.05$ & Shiping Chen \\
\hline $\mathrm{CN}-\mathrm{HaM}$ & GRA & AR & 0.14 & $3.33 \pm 1.41$ & $123.4 \pm 82.8$ & $91.6 \pm 56.9$ & $0.16 \pm 0.09$ & $0.15 \pm 0.08$ & Tomomichi Kato \\
\hline CN-Ku1 & EBF & DR & 0.29 & $0.49 \pm 0.33$ & $235.4 \pm 179.5$ & $31.6 \pm 19.5$ & $0.08 \pm 0.04$ & $0.11 \pm 0.05$ & Shiping Chen \\
\hline $\mathrm{CN}-\mathrm{Xi2}$ & GRA & TC & 0.18 & $1.03 \pm 0.61$ & $186.9 \pm 144.5$ & $28.3 \pm 13.8$ & $0.07 \pm 0.07$ & $0.14 \pm 0.09$ & Shiping Chen \\
\hline DE-Bay & ENF & TE & 0.34 & $4.52 \pm 1.37$ & $164.2 \pm 123.4$ & $132.6 \pm 48.4$ & $0.36 \pm 0.11$ & $0.54 \pm 0.42$ & Subke and Tenhunen (2004) \\
\hline DE-Geb & CRO & TE & 0.27 & $2.95 \pm 2.69$ & $249.1 \pm 258.8$ & $170.3 \pm 130.2$ & $0.33 \pm 0.19$ & $0.82 \pm 0.67$ & Anthoni et al. (2004) \\
\hline DE-Gri & GRA & TE & 0.12 & $2.72 \pm 0.96$ & $192.8 \pm 82.8$ & $92.3 \pm 56.6$ & $0.30 \pm 0.12$ & $0.97 \pm 0.76$ & Gilmanov et al. (2007) \\
\hline DE-Hai & DBF & TE & 0.61 & $3.33 \pm 1.63$ & $215.9 \pm 211.2$ & $140.7 \pm 113.7$ & $0.31 \pm 0.18$ & $0.78 \pm 0.83$ & Knohl et al. (2003) \\
\hline DE-Kli & CRO & TE & 0.24 & $3.96 \pm 1.50$ & $186.8 \pm 142.9$ & $169.4 \pm 174.2$ & $0.24 \pm 0.14$ & $0.52 \pm 0.47$ & Christian Bernhofer \\
\hline DE-Meh & MFO & TE & 0.07 & $3.30 \pm 1.66$ & $195.5 \pm 123.8$ & $114.4 \pm 129.5$ & $0.21 \pm 0.11$ & $0.47 \pm 0.44$ & Axel Don \\
\hline DE-Tha & ENF & TE & 0.39 & $3.17 \pm 1.37$ & $203.3 \pm 245.4$ & $126.2 \pm 77.9$ & $0.49 \pm 0.17$ & $1.00 \pm 0.77$ & Feigenwinter et al. (2004) \\
\hline DE-Wet & ENF & TE & 0.57 & $5.08 \pm 2.83$ & $177.8 \pm 138.5$ & $136.7 \pm 62.6$ & $0.43 \pm 0.15$ & $0.71 \pm 0.37$ & Anthoni et al. (2004) \\
\hline DK-Lva & GRA & TE & 0.22 & $3.36 \pm 1.54$ & $242.9 \pm 159.5$ & $117.0 \pm 88.8$ & $0.45 \pm 0.22$ & $0.70 \pm 0.90$ & Gilmanov et al. (2007) \\
\hline DK-Sor & DBF & TE & 0.64 & $5.14 \pm 3.17$ & $247.7 \pm 206.9$ & $114.4 \pm 92.1$ & $0.47 \pm 0.22$ & $0.51 \pm 0.57$ & Pilegaard et al. (2003) \\
\hline ES-ES1 & ENF & SM & 0.44 & $1.98 \pm 0.79$ & $245.3 \pm 235.6$ & $102.8 \pm 47.5$ & $0.27 \pm 0.11$ & $0.37 \pm 0.24$ & Sanz et al. (2004) \\
\hline ES-ES2 & CRO & SM & 0.08 & $1.10 \pm 0.77$ & $443.2 \pm 388.7$ & $219.2 \pm 153.9$ & $0.28 \pm 0.18$ & $0.47 \pm 0.36$ & Maria Jose Sanz \\
\hline ES-LMa & SAV & SM & 0.11 & $2.24 \pm 1.01$ & $113.3 \pm 86.9$ & $85.0 \pm 64.2$ & $0.19 \pm 0.10$ & $0.35 \pm 0.40$ & Maria Jose Sanz \\
\hline ES-VDA & GRA & TE & 0.11 & $2.15 \pm 0.39$ & $152.4 \pm 89.4$ & $59.7 \pm 15.1$ & $0.15 \pm 0.05$ & $0.10 \pm 0.06$ & Gilmanov et al. (2007) \\
\hline FI-Hyy & ENF & BO & 0.48 & $3.26 \pm 3.65$ & $214.2 \pm 201.9$ & $105.1 \pm 90.4$ & $0.30 \pm 0.13$ & $0.47 \pm 0.43$ & Suni et al. (2003) \\
\hline Fl-Kaa & WET & BO & 0.28 & $1.43 \pm 0.46$ & $158.7 \pm 70.0$ & $35.2 \pm 14.2$ & $0.19 \pm 0.07$ & $0.06 \pm 0.04$ & Aurela et al. (2001) \\
\hline FR-Gri & CRO & TE & 0.35 & $4.53 \pm 8.55$ & $297.4 \pm 261.5$ & $128.7 \pm 131.5$ & $0.29 \pm 0.15$ & $0.30 \pm 0.26$ & Pierre Cellier \\
\hline FR-LBr & ENF & TE & 0.27 & $3.77 \pm 1.37$ & $212.3 \pm 144.3$ & $153.9 \pm 61.2$ & $0.38 \pm 0.13$ & $0.64 \pm 0.55$ & Berbigier et al. (2001) \\
\hline FR-Lq2 & GRA & TE & 0.26 & $4.39 \pm 1.75$ & $176.9 \pm 193.0$ & $131.7 \pm 83.1$ & $0.31 \pm 0.19$ & $0.26 \pm 0.14$ & Gilmanov et al. (2007) \\
\hline FR-Pue & EBF & SM & 0.26 & $2.27 \pm 0.94$ & $182.6 \pm 165.7$ & $97.4 \pm 74.5$ & $0.28 \pm 0.10$ & $0.76 \pm 0.62$ & Rambal et al. (2003) \\
\hline HU-Mat & GRA & TE & 0.15 & $2.28 \pm 1.28$ & $163.0 \pm 107.6$ & $76.1 \pm 69.4$ & $0.19 \pm 0.09$ & $0.19 \pm 0.11$ & Zoltan Tuba \\
\hline IE-Dri & GRA & TE & 0.37 & $4.53 \pm 1.71$ & $199.3 \pm 128.5$ & $149.8 \pm 61.3$ & $0.48 \pm 0.17$ & $0.39 \pm 0.22$ & Gerard Kiely \\
\hline IL-Yat & ENF & DR & 0.36 & $1.21 \pm 0.88$ & $276.7 \pm 301.2$ & $63.1 \pm 54.3$ & $0.22 \pm 0.10$ & $0.52 \pm 0.39$ & Reichstein et al. (2005) \\
\hline IS-Gun & DBF & $\mathrm{TE}$ & 0.09 & $2.74 \pm 0.86$ & $232.7 \pm 129.2$ & $119.8 \pm 71.7$ & $0.38 \pm 0.18$ & $0.89 \pm 1.51$ & Sigurdsson et al. (2001) \\
\hline IT-Amp & GRA & SM & 0.09 & $3.16 \pm 1.88$ & $129.5 \pm 106.7$ & $74.4 \pm 48.7$ & $0.30 \pm 0.13$ & $0.29 \pm 0.20$ & Gilmanov et al. (2007) \\
\hline IT-BCi & $\mathrm{CRO}$ & SM & 0.16 & $2.22 \pm 1.37$ & $312.9 \pm 169.8$ & $406.0 \pm 570.4$ & $0.35 \pm 0.18$ & $0.83 \pm 0.81$ & Reichstein et al. (2003) \\
\hline IT-Be2 & CRO & TE & 0.10 & $3.11 \pm 1.34$ & $148.0 \pm 92.6$ & $95.2 \pm 132.7$ & $0.20 \pm 0.10$ & $0.58 \pm 0.71$ & Alessandro Peressotti \\
\hline IT-Col & DBF & SM & 0.66 & $2.54 \pm 0.84$ & $181.4 \pm 144.5$ & $151.6 \pm 75.6$ & $0.44 \pm 0.21$ & $1.06 \pm 0.80$ & Valentini et al. (1996) \\
\hline IT-Cpz & EBF & SM & 0.24 & $2.40 \pm 1.08$ & $296.2 \pm 330.8$ & $177.9 \pm 238.5$ & $0.36 \pm 0.16$ & $0.98 \pm 1.03$ & Reichstein et al. (2002) \\
\hline IT-MBo & GRA & TE & 0.13 & $5.19 \pm 2.04$ & $208.3 \pm 191.6$ & $199.9 \pm 141.6$ & $0.26 \pm 0.13$ & $0.27 \pm 0.23$ & Rodeghiero and Cescatti (2005) \\
\hline IT-Noe & $\mathrm{CSH}$ & SM & 0.11 & $2.24 \pm 0.88$ & $159.3 \pm 141.8$ & $79.8 \pm 36.3$ & $0.26 \pm 0.10$ & $0.61 \pm 0.51$ & Rossi et al. (1998) \\
\hline IT-Non & DBF & SM & 0.12 & $3.00 \pm 0.99$ & $131.3 \pm 93.3$ & $153.4 \pm 96.9$ & $0.31 \pm 0.12$ & $1.15 \pm 0.87$ & Reichstein et al. (2003) \\
\hline IT-Pia & $\mathrm{OSH}$ & SM & 0.52 & $0.56 \pm 0.42$ & $330.9 \pm 29.8$ & $46.4 \pm 36.6$ & $0.15 \pm 0.09$ & $0.14 \pm 0.11$ & Reichstein et al. (2005) \\
\hline IT-Ren & ENF & TE & 0.38 & $3.67 \pm 3.02$ & $316.4 \pm 277.2$ & $116.2 \pm 77.0$ & $0.32 \pm 0.17$ & $0.24 \pm 0.18$ & Rebmann et al. (2005) \\
\hline IT-Ro1 & DBF & SM & 0.28 & $2.65 \pm 1.12$ & $250.2 \pm 203.2$ & $109.5 \pm 79.5$ & $0.25 \pm 0.11$ & $0.52 \pm 0.39$ & Tedeschi et al. (2005) \\
\hline JP-Tak & DBF & TC & 0.41 & $2.71 \pm 1.38$ & $281.0 \pm 265.1$ & $103.1 \pm 110.7$ & $0.30 \pm 0.18$ & $0.56 \pm 0.54$ & Yamamoto et al. (1999) \\
\hline JP-Tef & MFO & TC & 0.40 & $4.49 \pm 1.67$ & $159.3 \pm 102.6$ & $107.3 \pm 59.1$ & $0.32 \pm 0.14$ & $0.53 \pm 0.36$ & Kentaro Takagi \\
\hline JP-Tom & MFO & TC & 0.31 & $4.57 \pm 2.00$ & $176.4 \pm 137.6$ & $156.3 \pm 117.0$ & $0.54 \pm 0.29$ & $0.38 \pm 0.29$ & Hirano et al. (2003) \\
\hline NL-Ca1 & GRA & TE & 0.22 & $3.17 \pm 1.45$ & $140.4 \pm 84.7$ & $105.2 \pm 61.8$ & $0.29 \pm 0.15$ & $0.22 \pm 0.16$ & Gilmanov et al. (2007) \\
\hline NL-Loo & ENF & TE & 0.33 & $3.97 \pm 1.49$ & $220.3 \pm 207.2$ & $143.8 \pm 90.2$ & $0.50 \pm 0.15$ & $0.60 \pm 0.55$ & Dolman et al. (2002) \\
\hline
\end{tabular}

Seasonal variation in ecosystem

parameters derived from FLUXNET data

\section{Groenendijk et al.}

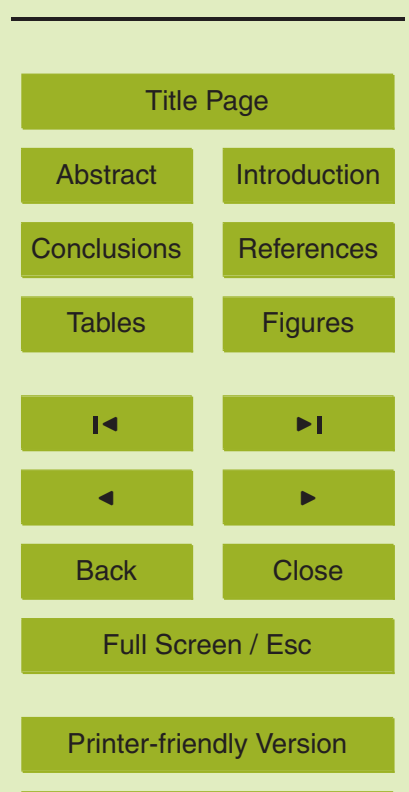

Interactive Discussion 


\begin{tabular}{|c|c|c|c|c|c|c|c|c|c|}
\hline Site & Vegetation & Climate & $u_{*}$ & $R_{\text {ref }}$ & $E_{0}$ & $J_{m}$ & $\alpha$ & $1 / \lambda$ & Reference or PI \\
\hline PT-Esp & EBF & SM & 0.48 & $2.17 \pm 1.16$ & $326.7 \pm 233.8$ & $130.8 \pm 38.9$ & $0.37 \pm 0.13$ & $1.11 \pm 0.85$ & Gabriel Pita \\
\hline PT-Mi1 & EBF & SM & 0.24 & $1.73 \pm 1.07$ & $152.4 \pm 110.9$ & $49.0 \pm 22.5$ & $0.18 \pm 0.12$ & $1.54 \pm 2.18$ & David et al. (2004) \\
\hline PT-Mi2 & GRA & SM & 0.13 & $2.02 \pm 1.49$ & $175.8 \pm 144.1$ & $79.3 \pm 70.7$ & $0.14 \pm 0.12$ & $0.30 \pm 0.19$ & Gilmanov et al. (2007) \\
\hline RU-Fyo & ENF & TC & 0.37 & $5.02 \pm 2.31$ & $211.8 \pm 203.0$ & $118.3 \pm 73.3$ & $0.45 \pm 0.17$ & $0.89 \pm 2.36$ & Andrej Varlagin \\
\hline RU-Ha1 & GRA & BO & 0.25 & $1.73 \pm 0.56$ & $181.2 \pm 127.7$ & $48.4 \pm 18.9$ & $0.19 \pm 0.06$ & $0.19 \pm 0.15$ & Dario Papale \\
\hline RU-Zot & ENF & BO & 0.60 & $2.13 \pm 1.21$ & $202.2 \pm 135.9$ & $76.9 \pm 34.9$ & $0.22 \pm 0.11$ & $0.40 \pm 0.29$ & Tchebakova et al. (2002) \\
\hline SE-Fla & ENF & BO & 0.48 & $2.43 \pm 1.63$ & $313.7 \pm 199.8$ & $55.8 \pm 33.0$ & $0.27 \pm 0.17$ & $0.28 \pm 0.20$ & Lindroth et al. (1998) \\
\hline UK-Gri & ENF & TE & 0.37 & $4.26 \pm 3.84$ & $215.4 \pm 166.2$ & $124.0 \pm 57.7$ & $0.54 \pm 0.16$ & $0.77 \pm 1.08$ & Valentini et al. (2000) \\
\hline US-ARb & GRA & SM & 0.44 & $2.53 \pm 1.47$ & $187.1 \pm 200.7$ & $222.6 \pm 198.1$ & $0.18 \pm 0.12$ & $0.42 \pm 0.36$ & Fischer et al. (2007) \\
\hline US-ARc & GRA & SM & 0.51 & $2.99 \pm 1.42$ & $96.0 \pm 76.5$ & $162.9 \pm 135.1$ & $0.17 \pm 0.09$ & $0.28 \pm 0.21$ & Fischer et al. (2007) \\
\hline US-Aud & GRA & DR & 0.16 & $0.65 \pm 0.46$ & $300.7 \pm 229.8$ & $58.0 \pm 66.6$ & $0.10 \pm 0.08$ & $0.30 \pm 0.32$ & Tilden Meyers \\
\hline US-Bkg & GRA & TC & 0.16 & $2.05 \pm 0.70$ & $165.1 \pm 90.4$ & $121.2 \pm 80.0$ & $0.19 \pm 0.05$ & $0.07 \pm 0.04$ & Gilmanov et al. (2005) \\
\hline US-Blo & ENF & SM & 0.25 & $2.55 \pm 1.48$ & $297.1 \pm 259.1$ & $158.1 \pm 101.9$ & $0.23 \pm 0.09$ & $0.42 \pm 0.33$ & Misson et al. (2005) \\
\hline US-Bn1 & ENF & BO & 1.06 & $1.34 \pm 0.87$ & $356.0 \pm 226.8$ & $32.6 \pm 18.5$ & $0.20 \pm 0.10$ & $0.23 \pm 0.14$ & Liu et al. (2005) \\
\hline US-Ho1 & ENF & TC & 0.27 & $3.60 \pm 1.67$ & $160.8 \pm 106.0$ & $121.1 \pm 67.8$ & $0.44 \pm 0.17$ & $0.83 \pm 0.50$ & Hollinger et al. (2004) \\
\hline US-IB1 & $\mathrm{CRO}$ & TC & 0.27 & $2.57 \pm 3.44$ & $431.8 \pm 284.5$ & $428.2 \pm 539.5$ & $0.31 \pm 0.16$ & $0.94 \pm 0.75$ & Sluis (2002) \\
\hline US-IB2 & GRA & $\mathrm{TC}$ & 0.09 & $2.79 \pm 1.10$ & $127.8 \pm 75.8$ & $152.7 \pm 109.2$ & $0.28 \pm 0.19$ & $0.35 \pm 0.28$ & Sluis (2002) \\
\hline US-KS2 & $\mathrm{CSH}$ & SM & 0.19 & $2.54 \pm 1.43$ & $191.7 \pm 194.9$ & $183.7 \pm 64.6$ & $0.24 \pm 0.06$ & $0.55 \pm 0.27$ & Powell et al. (2006) \\
\hline US-MMS & DBF & SM & 0.53 & $2.60 \pm 1.05$ & $161.6 \pm 118.6$ & $157.8 \pm 137.1$ & $0.30 \pm 0.13$ & $0.44 \pm 0.32$ & Schmid et al. (2000) \\
\hline US-MOz & DBF & SM & 0.51 & $2.81 \pm 1.59$ & $208.9 \pm 208.0$ & $149.2 \pm 138.6$ & $0.25 \pm 0.15$ & $0.51 \pm 0.40$ & Gu et al. (2006) \\
\hline US-NC2 & ENF & SM & 0.24 & $2.67 \pm 1.11$ & $302.1 \pm 215.1$ & $147.8 \pm 91.7$ & $0.60 \pm 0.19$ & $0.55 \pm 0.16$ & Jiquan Chen \\
\hline US-Ne1 & CRO & $\mathrm{TC}$ & 0.21 & $3.92 \pm 2.02$ & $191.9 \pm 139.2$ & $548.6 \pm 494.0$ & $0.32 \pm 0.18$ & $0.83 \pm 0.65$ & Verma et al. (2005) \\
\hline US-Ne2 & CRO & TC & 0.17 & $4.04 \pm 1.98$ & $172.1 \pm 117.4$ & $482.6 \pm 441.9$ & $0.33 \pm 0.17$ & $0.80 \pm 0.65$ & Verma et al. (2005) \\
\hline US-Ne3 & $\mathrm{CRO}$ & TC & 0.21 & $3.33 \pm 1.73$ & $206.4 \pm 115.9$ & $572.0 \pm 570.9$ & $0.32 \pm 0.16$ & $1.37 \pm 0.81$ & Verma et al. (2005) \\
\hline US-NR1 & ENF & BO & 0.44 & $2.79 \pm 0.86$ & $183.5 \pm 155.7$ & $62.4 \pm 25.7$ & $0.24 \pm 0.13$ & $0.20 \pm 0.12$ & Monson et al. (2002) \\
\hline US-PFa & MFO & TC & 0.36 & $3.25 \pm 1.48$ & $364.7 \pm 195.4$ & $144.2 \pm 89.4$ & $0.37 \pm 0.22$ & $0.22 \pm 0.24$ & Davis et al. (2003) \\
\hline US-SO2 & WSA & SM & 0.59 & $1.85 \pm 0.14$ & $175.6 \pm 163.8$ & $45.9 \pm 13.6$ & $0.62 \pm 0.08$ & $0.25 \pm 0.12$ & Hibbard et al. (2005) \\
\hline US-SO3 & WSA & SM & 0.32 & $0.92 \pm 1.08$ & $325.1 \pm 275.9$ & $29.0 \pm 15.1$ & $0.10 \pm 0.05$ & $0.12 \pm 0.08$ & Hibbard et al. (2005) \\
\hline
\end{tabular}

Seasonal variation in ecosystem

parameters derived from FLUXNET data

M. Groenendijk et al.

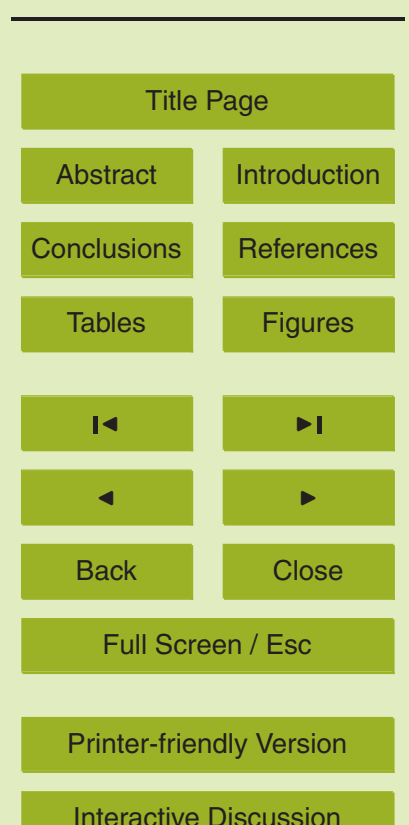

Interactive Discussion 
BGD

6, 2863-2912, 2009

Seasonal variation in ecosystem
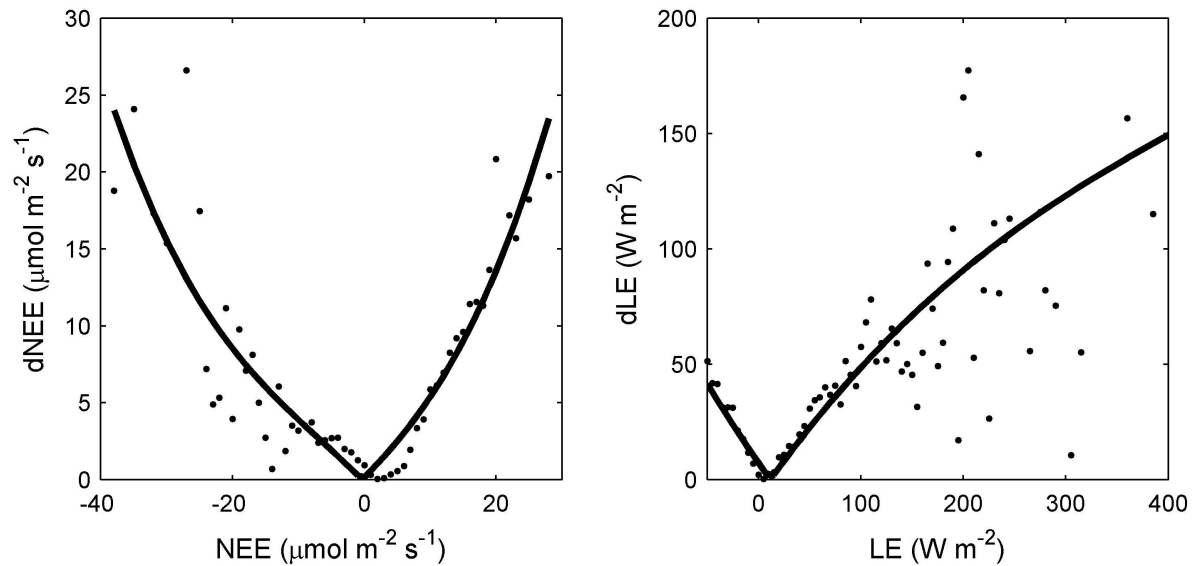

Fig. 1. Flux uncertainty ( $\mathrm{d} N E E$ and $\mathrm{d} L E$ ) derived from paired observation for $N E E$ and $L E$ at the NL-Loo site. The points are the binned average values, and in the line is the polynomial fit.

\section{parameters derived from FLUXNET data}

M. Groenendijk et al.

Title Page

Abstract

Introduction

Conclusions

References

Tables

Figures

14

$>$ I

4

Back

Close

Full Screen / Esc

Printer-friendly Version 
BGD

6, 2863-2912, 2009

Seasonal variation in ecosystem

parameters derived from FLUXNET data
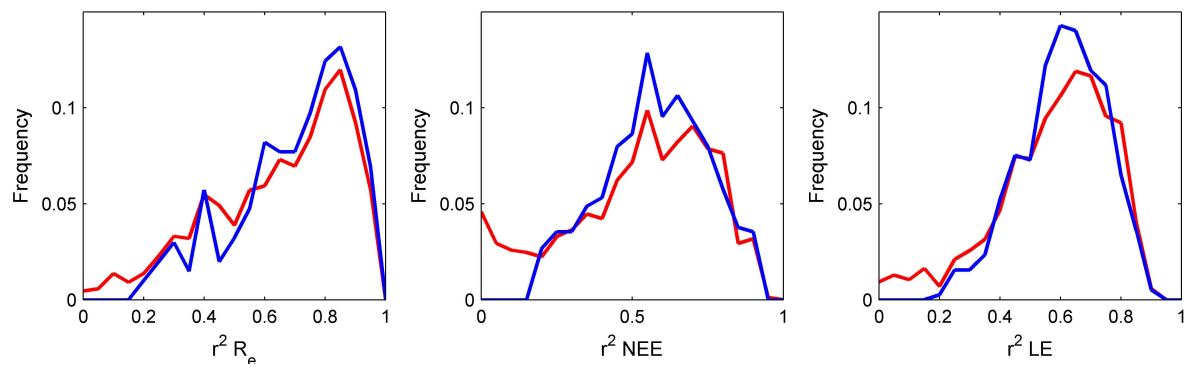

Fig. 2. Frequency distributions of site year correlation coefficients $\left(r^{2}\right)$ of half hourly observed and simulated $R_{e}, N E E$ and $L E$. Initial distribution in red and distribution after removal of sites as explained in the text in blue.
M. Groenendijk et al.

Title Page

Abstract

Introduction

Conclusions

References

Tables

Figures

14

$>$ I

$<$

Back

Close

Full Screen / Esc

Printer-friendly Version

Interactive Discussion 
BGD

6, 2863-2912, 2009

Seasonal variation in ecosystem

parameters derived from FLUXNET data
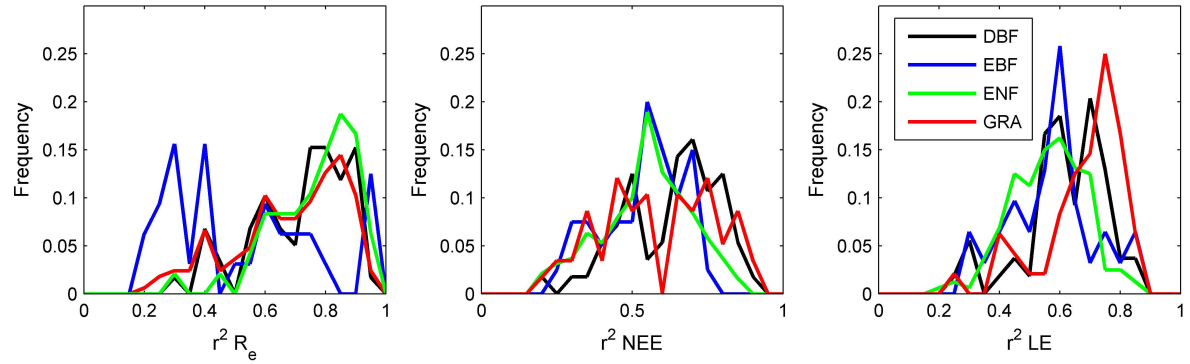

M. Groenendijk et al.

\section{Title Page}

Abstract

Introduction

Conclusions

References

Figures

Fig. 3. Frequency distributions of site year correlation coefficients $\left(r^{2}\right)$ of half hourly observed and simulated $R_{e}, N E E$ and $L E$. The different colors represent the following vegetation types: deciduous broadleaf forest (DBF), evergreen broadleaf forest (EBF), evergreen needleleaf forest (ENF) and grassland (GRA).
Tables

14

4

Back

\section{Full Screen / Esc}

Printer-friendly Version

Interactive Discussion 


$\longrightarrow$ Boreal $\longrightarrow$ Temp.-Cont. $\rightleftharpoons$ Subtr.-Med.
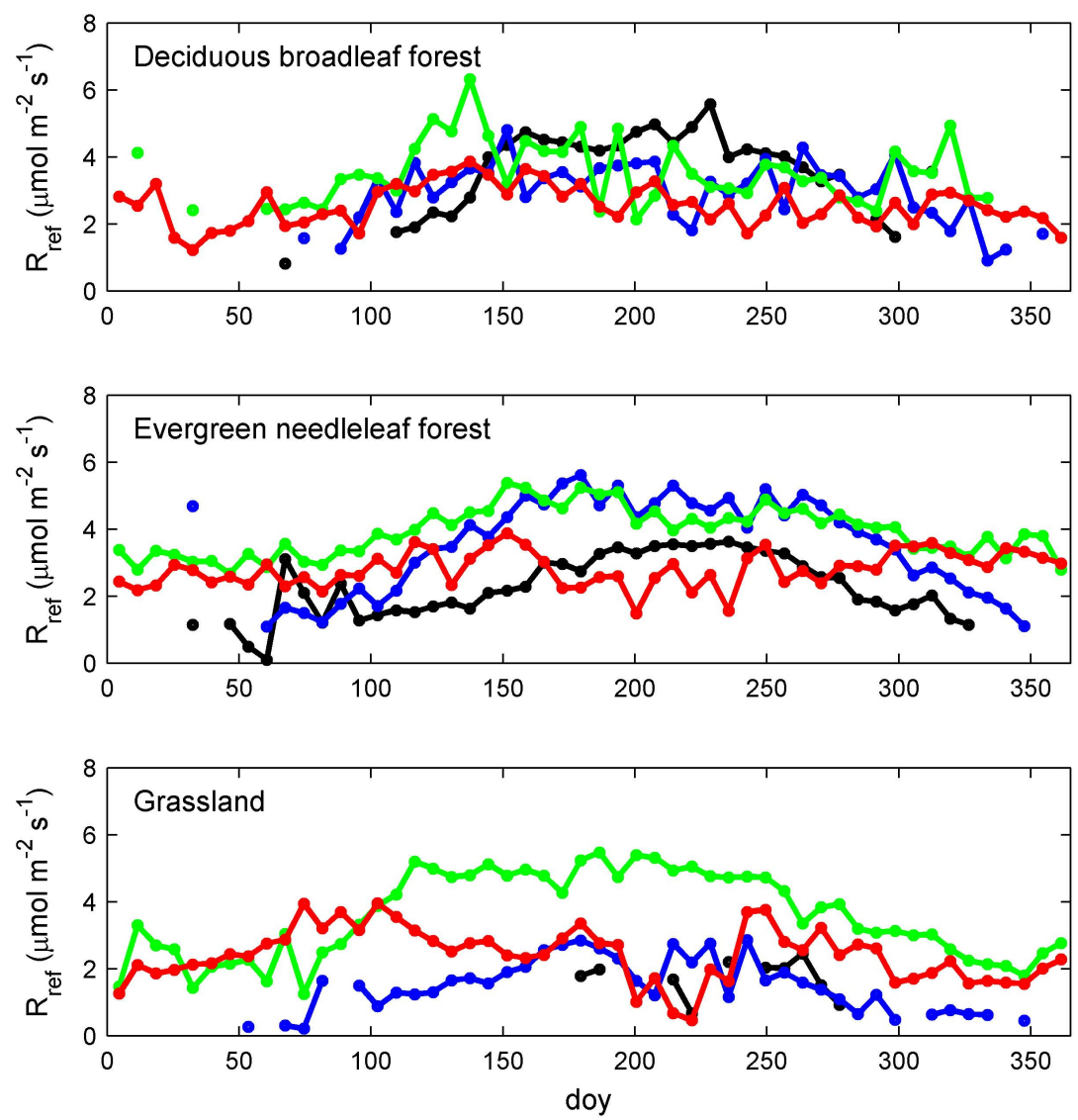

Fig. 4. Seasonal variation of $R_{\text {ref }}$ for different vegetation types and climate regions.
BGD

6, 2863-2912, 2009

Seasonal variation in ecosystem parameters derived from FLUXNET data

M. Groenendijk et al.

\section{Title Page}

Abstract

Introduction

Conclusions

References

Tables

Figures

14

$\rightarrow$

4

Back

Close

Full Screen / Esc

Printer-friendly Version

Interactive Discussion 


\section{$\longrightarrow$ Boreal $\longrightarrow$ Temp.-Cont. $\longrightarrow$ Temperate $\longrightarrow$ Subtr.-Med.}
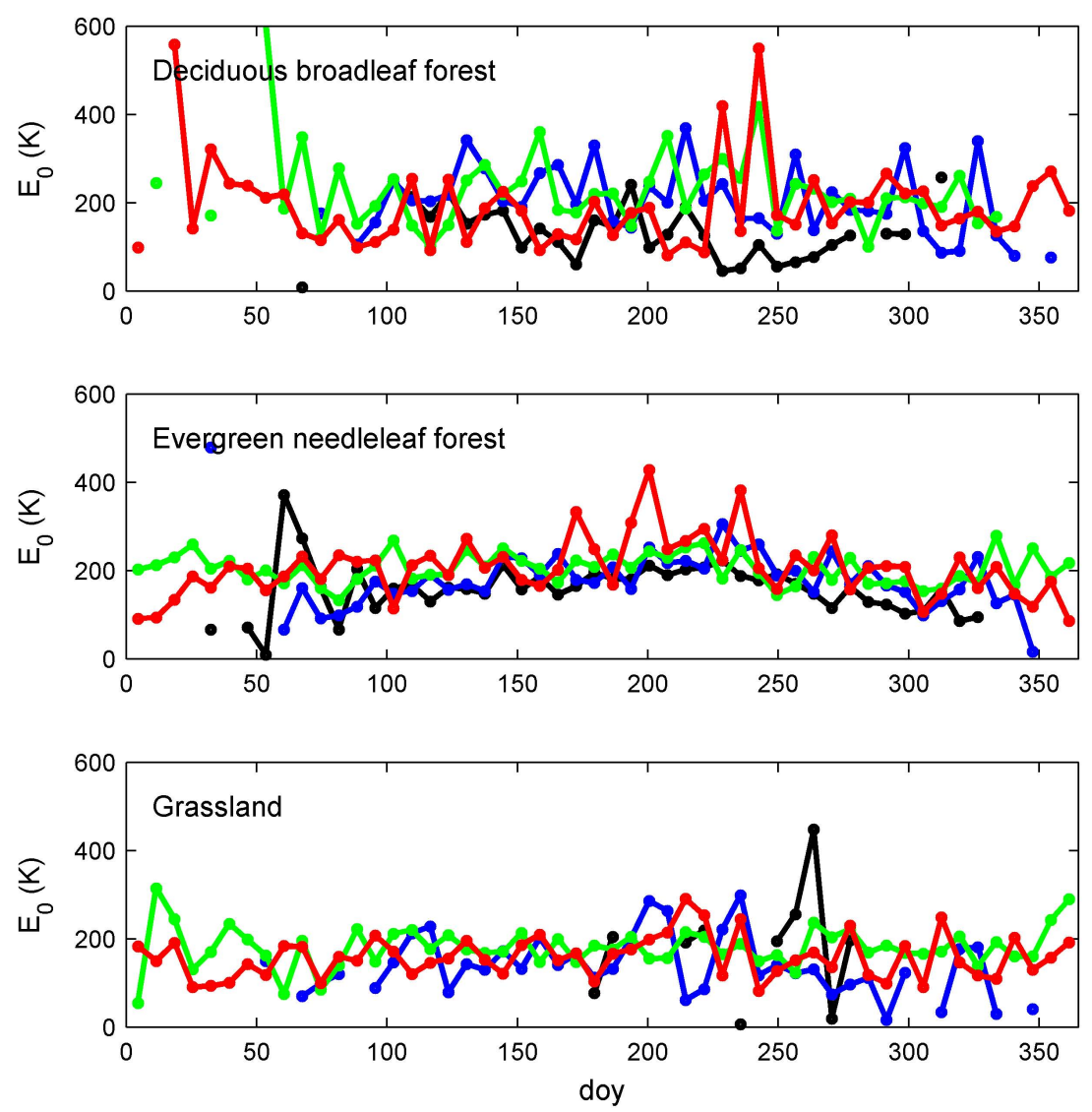

Fig. 5. Seasonal variation of $E_{0}$ for different vegetation types and climate regions.

\section{BGD}

6, 2863-2912, 2009

Seasonal variation in ecosystem parameters derived from FLUXNET data

\section{Groenendijk et al.}

\section{Title Page}

Abstract

Introduction

Conclusions

References

Tables

Figures

14

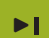

4

Back

Close

Full Screen / Esc

Printer-friendly Version

Interactive Discussion

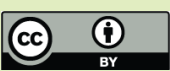



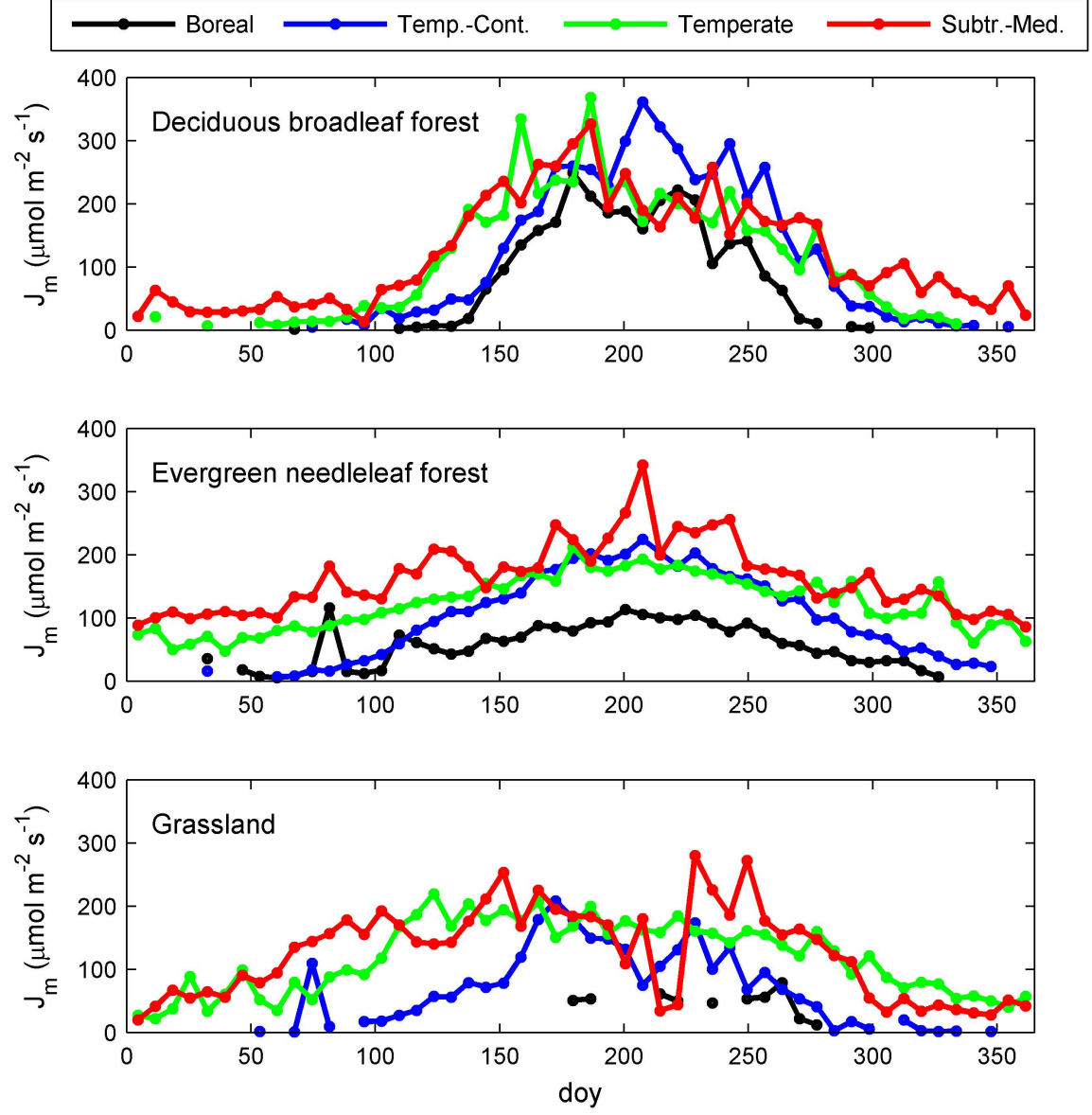

Fig. 6. Seasonal variation of $J_{m}$ for different vegetation types and climate regions.

\section{BGD}

6, 2863-2912, 2009

Seasonal variation in ecosystem parameters derived from FLUXNET data

\section{Groenendijk et al.}

\section{Title Page}

Abstract

Conclusions

Tables

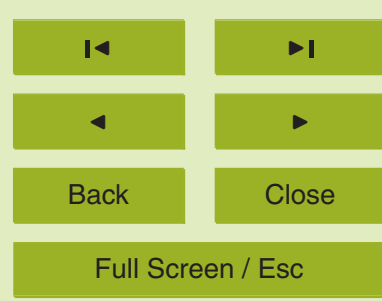

Printer-friendly Version 


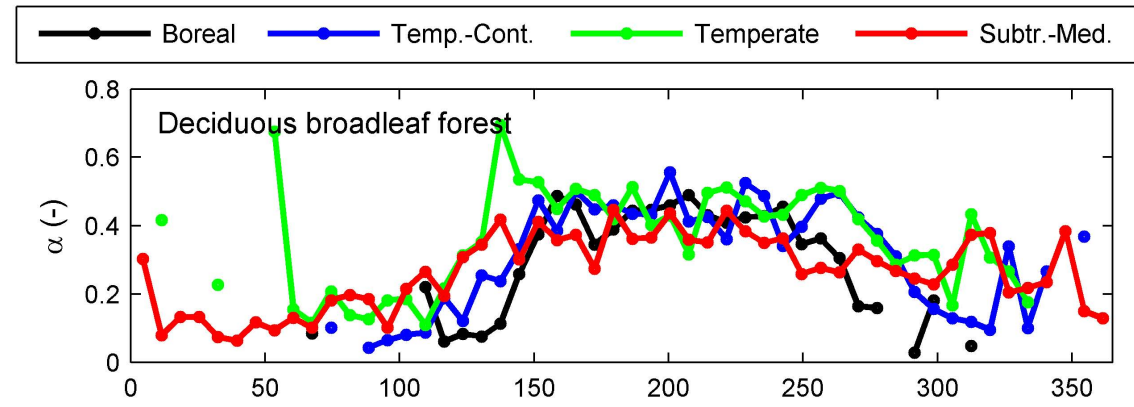

\section{BGD}

6, 2863-2912, 2009

Seasonal variation in ecosystem

parameters derived from FLUXNET data

\section{Groenendijk et al.}

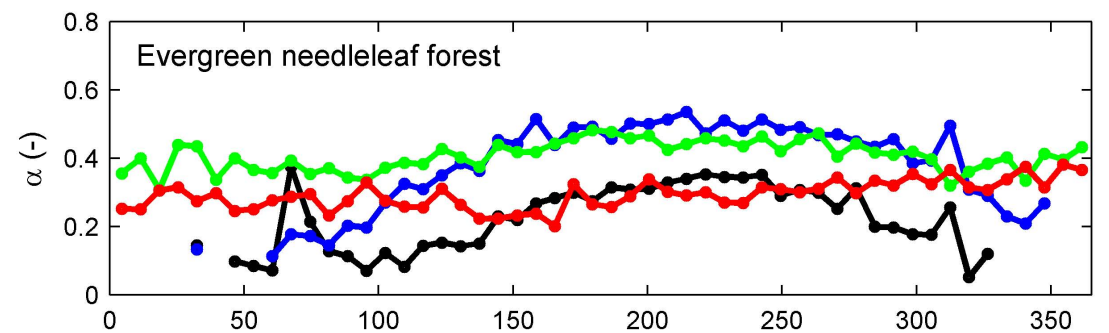

Title Page

Abstract

Introduction

Conclusions

References

Tables

Figures
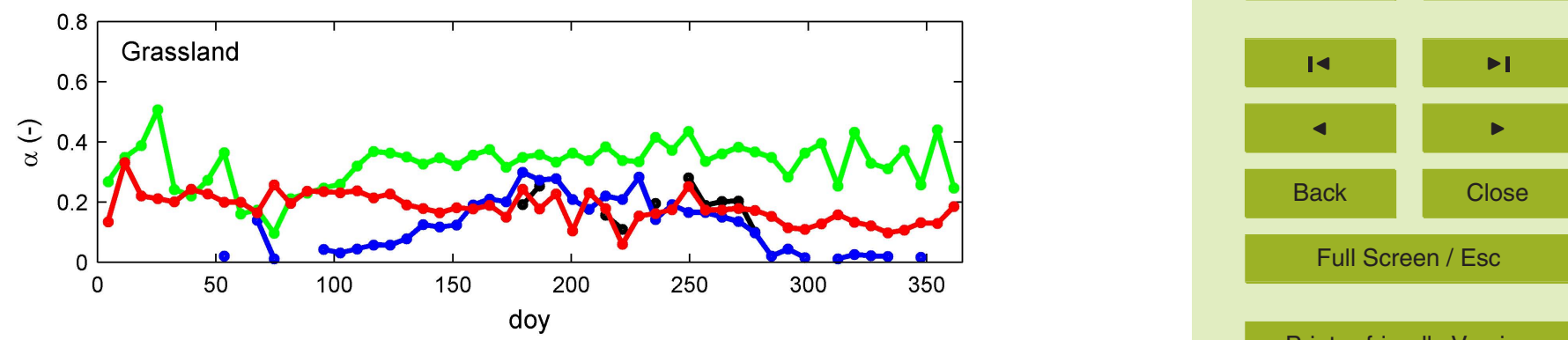

Printer-friendly Version

Fig. 7. Seasonal variation of $\alpha$ for different vegetation types and climate regions.

Interactive Discussion 


$\longrightarrow$ Boreal $\longrightarrow$ Temp.-Cont. $\rightleftharpoons$ Subtr.-Med.

\section{BGD}
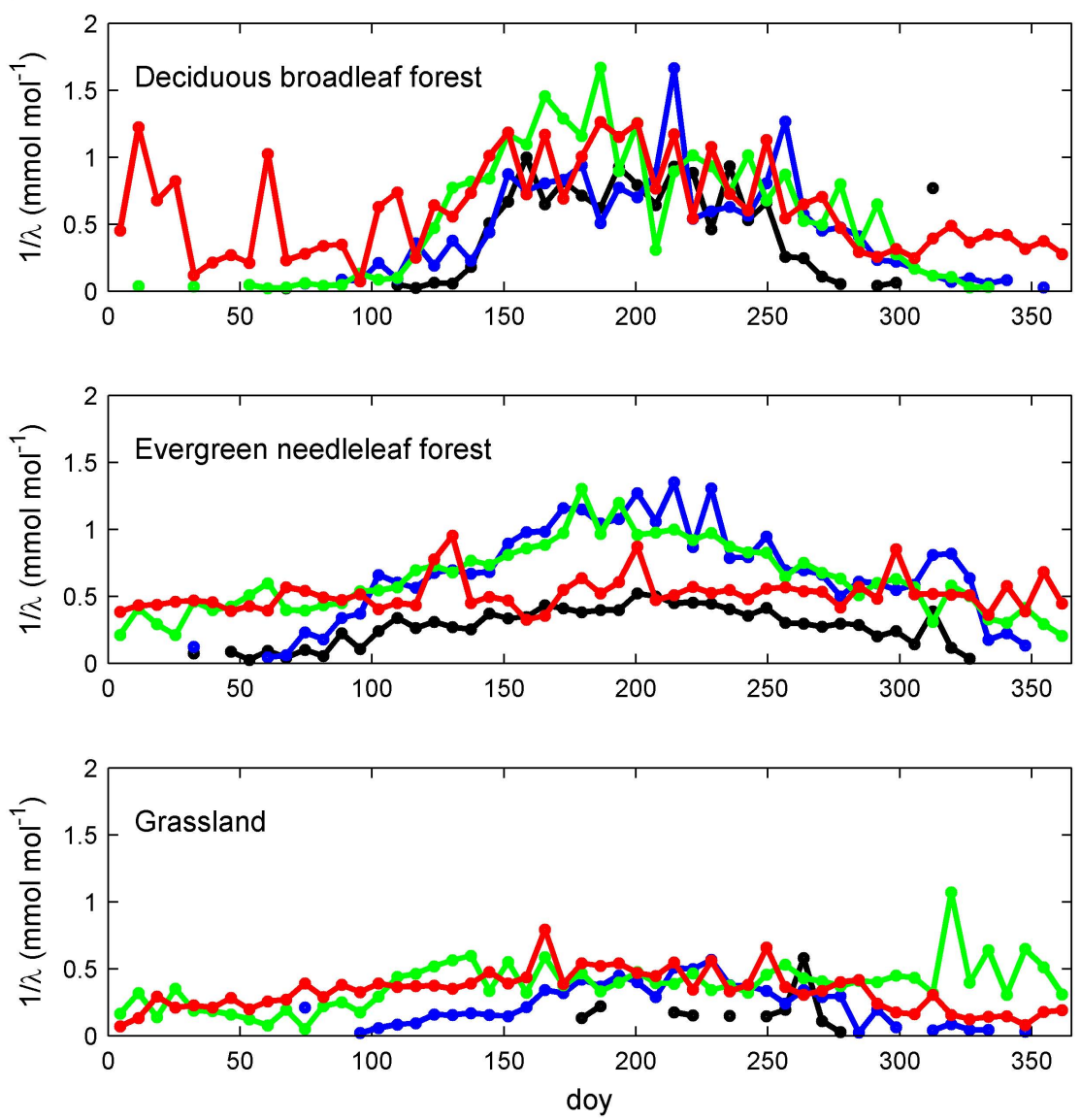

6, 2863-2912, 2009

Seasonal variation in ecosystem parameters derived from FLUXNET data

M. Groenendijk et al.

\section{Title Page}

Abstract

Introduction

Conclusions

References

Tables

Figures

14

- I

4

Back

Close

Full Screen / Esc

Printer-friendly Version

Interactive Discussion

Fig. 8. Seasonal variation of $1 / \lambda$ for different vegetation types and climate regions. 